\title{
Intra-industry trade and implications of the European Union-Japan Economic Partnership Agreement from the perspective of the automotive industry
}

\author{
Bogusława Drelich-Skulska, Sebastian Bobowski
}

\begin{abstract}
A B S T R A C T
Objective: The objective of the article is to identify patterns of intra-industry trade between the European Union (EU) and Japan in the automotive industry and to provide implications of key provisions of the EU-Japan Economic Partnership Agreement (EPA) for this sector.

Research Design \& Methods: We conducted an analysis of intra-industry trade disaggregated into 65 six-digit HS tariff codes using the UN Comtrade database.

Findings: Our results confirm the potential of intra-industry trade in the automotive industry, reflected by its increasing volume, as well as the role of high-quality vertical intra-industry trade (VIIT). From the perspective of the EU, it is important to stress the improvement of the trade balance with Japan in the automotive industry and the rising position of Japan as an EU trade partner. Trade liberalisation under the EU-Japan EPA, including both tariff and non-tariff measures, may contribute to the further expansion of the EU-Japan bilateral trade in the automotive industry. However, mid- and long-term trends in intra-industry flows, including their horizontal and vertical patterns, depend on the industry's competitiveness and corresponding quality and cost differences.

Implications \& Recommendations: The authors studied regulatory implications of the EU-Japan EPA for the automotive industry, including sectoral Annexes and Appendix of the EPA. The authors pointed to theoretical and empirical objections in the research process, related mostly to the degree of the disaggregation of statistics and the choice of trade nomenclature. The necessity of further research was stressed at the disaggregated country-country level to eliminate distortions of data on the IIT patterns and verify the relevance of countryand industry-specific determinants of trade, including FDI. Detailed studies of implications of the EU-Japan EPA should be undertaken in one year, when regulatory frameworks of the EU-UK and UK-Japan trade relations will be finally agreed upon and formalised.
\end{abstract}

Contribution \& Value Added: The automotive industry is an important contributor to employment, GDP and R\&D expenditures for both the EU and Japan. Therefore, trends in intra-industry trade and the EPA's implications in this sector deserve attention and in-depth analysis. To the best of our knowledge, there has been no such industry-level analysis of the EU-Japan EPA so far. The authors considered consequences of Brexit for the automotive industry, including various scenarios of the future EU-UK and Japan-UK trade relations.

\begin{tabular}{ll}
\hline Article type: & research article \\
Keywords: & EU-Japan EPA; intra-industry trade; automotive industry \\
JEL codes: & F14, F15
\end{tabular}

Received: 24 November $2020 \quad$ Revised: 17 March $2021 \quad$ Accepted: 4 April 2021

\section{Suggested citation:}

Drelich-Skulska, B., \& Bobowski, S. (2021). Intra-industry trade and implications of the European Union-Japan Economic Partnership Agreement from the perspective of automotive industry. Entrepreneurial Business and Economics Review, 9(2), 183-206. https://doi.org/10.15678/EBER.2021.090212

\section{INTRODUCTION}

The European Union-Japan Economic Partnership Agreement (EPA) was signed on 17 July 2018 in Tokyo (Japan) and entered into force on 1 February 2019. It was notified by the World Trade Organisation (WTO) on 14 January 2019 under Article 24 of General Agreement on Tariffs and Trade (GATT) and 
Article 5 of General Agreement on Trade in Services (GATS), as it covers trade in both goods and services. The EPA eliminates $97 \%$ of customs duties on EU imports to Japan, amounting to more than USD 1 billion every year. According to the European Commission (2019) estimations, full implementation of the EPA will increase annual trade between the EU and Japan by USD 36 billion.

As a manifestation of mega-regionalism, the EPA constitutes the world's largest trade bloc so far, accounting for $27.34 \%$ of global GDP and $36.32 \%$ of global exports in 2019 and inhabited by over 572 million people (World Bank Database, 2020). The bloc contains five of the seven major advanced economies in the world (G7), i.e. Japan, Germany, United Kingdom ${ }^{1}$, France and Italy. Merchandise trade between the EU and Japan amounted to USD 157.3 billion in 2019, with EU exports to Japan totalling USD 74.9 billion and imports of USD 82.4 billion. Japan is the second-largest trade partner of the EU in Asia (after China), while the EU is the largest foreign investor in Japan. In 2019, the EU's foreign direct investment (FDI) in Japan amounted to USD 6.86 billion, which is the second-highest amount since 2010. On the other hand, Japan's investment in the EU reached USD 72.74 billion in 2019, the highest amount since 2010, accounting for 29\% of total outward FDI flows from Japan (Statista, 2020; Statista, 2020a).

As argued by Bobowski (2017, pp. 25-26), the EPA affords both the EU and Japan "an opportunity to set multilateral rules of trade in the 21st century and challenge the hegemonic ambitions of the United States and China at both the regional and global stage." The former President of the European Commission, Jean-Claude Juncker, called the EU-Japan EPA a "(...) a message to the world about the future of open and fair trade" (EC, 2019). US President Donald Trump and his administration were obvious addressees of this statement. On 23 January 2017, the newly elected president had signed an executive order withdrawing the United States from the Trans-Pacific Partnership (TPP) agreement, claiming that the agreement was a threat to the domestic economy, industry and labour market. This act represented a symbolic retreat from trade policy defined by multilateralism and mega-regionalism in favour of nationalism and protectionism under the slogan "America first." Moreover, the so-called Paris climate agreement signed on 12 December 2015 in Paris, from which Trump also decided to withdraw his country, became a subject of special commitments under the EU-Japan Strategic Partnership Agreement (SPA).

The main objective of this article is to identify patterns of intra-industry trade between the European Union (EU) and Japan in the automotive industry and to provide implications of the EU-Japan EPA's key provisions for this sector. The automotive industry is an important contributor to employment, GDP and R\&D expenditures for both the EU and Japan. Therefore, trends in intra-industry trade and the EPA's implications in this sector deserve attention and in-depth analysis. To the best of our knowledge, there has been no such an industry-level analysis of the EU-Japan EPA so far. Most of empirical analyses of the EU-Japan bilateral trade liberalisation focus on the EPA's effects on the EU as a whole, i.e. Sunesen, Francois, and Thelle (2010), Francois, Manchin, and Norberg (2011), or at the industry-level of individual EU member states and Japan, i.e. Ambroziak (2017), Felbermayr, Kimura, Okubo, Steininger, and Yalcin (2017). The importance of intra-industry trade in the EU-Japan bilateral trade was taken into account for the first time by Benz and Yalcin (2015), however, the authors adopted a CGE model at the aggregated level of data.

The EPA consists of 23 chapters and annexes. Annexes 2-C, 3-B and Appendix 3-B-1 contain provisions addressing the automotive industry. In addition to regulations dedicated to trade in goods and services, the agreement covers rules of origin, government procurement, intellectual property, capital movements, subsidies, state-owned enterprises, dispute settlement, sustainable development, and small and medium-sized enterprises, among other areas.

In addition to the EPA, the EU-Japan SPA was signed on 17 July 2018 to establish a legal framework for strategic cooperation in such fields as democracy promotion and human rights; peace and security; combatting terrorism; chemical, biological, radiological and nuclear risk mitigation; development policy; economic, financial and industrial cooperation; transport; climate change; energy and science,

\footnotetext{
${ }^{1}$ According to a note verbale from the EU (WT/LET/1462) dated 27 January 2020, the United Kingdom was treated as an EU member for the purposes of executing international agreements until the end of the transition period, i.e. 31 December 2020. The Withdrawal Agreement concluded under Article 50 of the Treaty of the EU assumed that the EU law - with few exceptions - still applied to and in the UK.
} 
technology and innovation. Furthermore, the EU and Japan are currently negotiating the Investment Protection Agreement (IPA) which provides investor-state and state-state dispute settlement mechanisms (ISDS and SSDS).

The EPA (in force), SPA (pending ratification) and IPA (under negotiation) co-create a legal framework covering political and sectoral cooperation and the joint activities of the EU and Japan in the face of regional and global challenges (EC, 2019). By strengthening bilateral economic and political ties, the EU-Japan EPA and SPA enhance the institutionalisation of the security community of the EU and members of the Democratic Security Diamond (Kuźnar \& Menkes, 2019, p. 9).

The novelty of this article is to adopt the perspective of the automotive industry to identify the patterns of the EU-Japan intra-industry trade disaggregated into six-digit HS codes, as well as to discuss key provisions of the EU-Japan EPA and their implications. Therefore, this article will seek for the answer to the following research questions:

RQ1: What were the trends in respect of the shares of the automotive industry in total trade between the EU and Japan in recent period?

RQ2: What were the patterns of intra-industry trade in the automotive industry between the $\mathrm{EU}$ and Japan in recent period?

RQ3: What are the implications of the EU-Japan EPA's key provisions for the automotive industry in the EU and Japan?

This article proceeds as follows. Section 2 reviews the literature on intra-industry trade and empirical studies on the EU-Japan EPA published to date. Section 3 describes the automotive industry in the EU and Japan, including recent statistics. Section 4 describes our research methodology and examines the patterns of intra-industry trade in the automotive industry, including motor vehicles and their parts and equipment, using the UN Comtrade database. Section 5 presents and discusses the study's results. This section is followed by our conclusions.

\section{LITERATURE REVIEW}

\section{Intra-industry trade}

Intra-industry trade, considered as simultaneous exports and imports within the same tariff codes or product groups, was recognised as a newly emerging phenomenon in the early 1960 s. Numerous trade theorists, including Kojima (1964), Linder (1961) and Posner (1961), highlighted that trade between developed countries with similar income levels and development, including goods of similar factor endowment, increased as a share of total world turnover. Due to the inadequacy of explanations for this phenomenon provided by, among others, the Heckscher-Ohlin-Samuelson (HOS) paradigm and Leontief analysis, demand- and supply-side theories of intra-industry trade emerged.

The conceptualisation of intra-industry trade from the demand-side perspective was advanced by, among others, Lancaster (1980), Linder (1961) and Helpman (1981). From the supply side, Helpman (1981), Krugman (1981) and Helpman and Krugman (1985) made key contributions. The demand-side theories stressed the importance of the diversification of consumer preferences and tastes, linking an increase in intra-industry trade with countries' rising income. In turn, these factors influence purchasing decisions and stimulate demand for more unique and specific goods. The progressive homogenisation of consumer preferences and tastes across countries at similar development and income levels has been recognised as a source of international trade in varieties of the same products (Bobowski, 2018). From the supply-side perspective, intra-industry trade results from manufacturing capabilities in the field of product differentiation. Helpman and Krugman (1985) argued that a higher average income per capita is related to a higher capital-labour endowment ratio. This, in turn, enhances a country's intra-industry specialisation, as capital-intensive industries deliver more differentiated outputs (Bergstrand, 1990). According to theories on both the demand and supply sides, trade in differentiated products takes place mainly between countries at similar levels of income, development and factor endowments. 
Horizontal intra-industry trade models were introduced by Krugman (1979; 1981), Dixit and Norman (1980), Lancaster (1980), Helpman (1981) and Bergstrand (1990), including assumptions of horizontal differentiation of products and increasing returns of scale. Mora (2002) noted several prerequisites of those models, including high income, monopolistic market competition, similar levels of economic development and relative factor endowments, diversified consumer preferences and products of similar quality but different attributes. The increasing volume of intra-industry trade between developed and developing countries inspired some authors to model vertical intra-industry trade. Falvey (1981) and Falvey and Kierzkowski (1987) analysed intra-industry trade in vertically differentiated products, with the assumption of constant returns of scale in line with the theorem of Heckscher-Ohlin-Samuelson.

While the horizontal share of total intra-industry trade is generally understood to increase with the similarity of factor endowments between countries, vertical intra-industry trade is fuelled by their divergence. Therefore, as Hellvin (1996) argued, vertical intra-industry trade involves countries at diversified levels of income per capita, while horizontal trade involves countries at similar levels. In the latter case, horizontal product differentiation and economies of scale play an important role. Price competition between manufacturers (when offsetting net transportation costs) makes the trade in homogenous goods socially profitable (Kierzkowski, 1996). Brander (1981) and Williamson and Milner (1991) highlighted the potential of such trade between countries with similar income levels, technological development, factor endowments and consumer preferences.

Empirical analyses of intra-industry trade have been conducted since the 1960 s by authors including Verdoorn (1960), Kojima (1964), Balassa (1966), Grubel and Lloyd (1971) and Greenaway and Milner (1981; 1983). Greenaway $(1983 ; 1984)$ and Balassa (1986) established databases of intra-industry trade. Grubel and Lloyd (1975) recognised preference diversity instead of relative factor endowments as a trigger of intra-industry trade. Dixit and Stiglitz (1977) addressed the assumptions of monopolistic competition and consumers' product variety preferences in their studies on intra-industry trade. The authors recognised product differentiation through the prism of increasing returns of scale, as in the case of Lancaster (1979). However, the latter examined product differentiation as a source of demand at the aggregate level. Dixit and Stiglitz (1977) and Lancaster (1979) also shared assumptions of non-competitive reasons for diversified consumer preferences and imperfect competition (Kierzkowski, 1984).

\section{The European Union-Japan EPA}

Several authors have investigated the economic and strategic impact of the EU-Japan EPA. De Prado (2017) considered the long-term impact of the EU-Japan EPA and SPA, stating that the mutual convergence and adjustment of economic models and security paradigms are critical to building a more comprehensive and substantial partnership. Felbermayr et al. (2017) analysed the EU-Japan EPA using the static, general equilibrium trade model to assess the sectoral value-added impacts in both the EU and Japan. The authors confirmed that gains will be asymmetrically distributed across the sectors and countries, making pharmaceutical, food and automotive industries the largest beneficiaries, with special regard to enterprises operating in Germany, France, the United Kingdom and the Netherlands. Bobowski (2017) studied the implications of the EU-Japan EPA, recognising economic gains in the fields of trade and investment that may translate into job creation, technology transfer, rising productivity and improved social welfare in the EU, while also pointing out marginal social and environmental concerns. Ambroziak (2017) studied the impact of the EU-Japan EPA on trade in agricultural products in Poland, recognizing opportunities in respect of export growth. Suzuki (2017) found that the stance of civil society organisations (CSOs) toward the EU-Japan EPA was relatively mild, contrary to other mega-regional agreements such as CETA or TTIP, mostly due to its 'old-fashioned' agenda and the lower importance of Japan in the EU's international trade in comparison to its North American partners.

Felbermayr (2018) conducted a quantitative analysis of the EU-Japan EPA, employing a generalised variant of the Eaton-Kortum model. The authors identified no relevant side effects for the third countries, while the largest gains were expected due to reductions in the costs of non-tariff barriers. Danks (2018) studied the EU-Japan EPA and SPA through the prism of the strategic doctrine of Japan, referred to as Abe's Doctrine, concluding that both agreements serve to reinforce the rules-based, liberal inter- 
national order and to modify Japan's domestic norms. According to the European Commission's Directorate-General for Trade (2018) estimates, the EPA will increase the EU exports to Japan by EUR 14 billion, and from Japan to the EU by EUR 22 billion. Przeździecka, Górska, Kuźnar, and Menkes (2019) used the CGE model to investigate the impact of the elimination of customs duties under the EU-Japan EPA for the Polish economy, highlighting prospective gains for producers of meat and animal products. Grübler, Reiter and Stehrer (2019), adopting a structural gravity model, estimated mid-term effects of the EU-Japan EPA on the real GDP of the EU and Japan, indicating a considerable positive impact on mid- and high-tech industries, except for CEE countries. Kuźnar and Menkes (2019a) confirmed the significance of the EU-Japan EPA and SPA rooted in the community of values. The authors noted endogenous and exogenous determinants of the agreements, such as the economic and political potentials of the parties, as well as the turbulent international environment that began with the isolationist policies of the US administration under Trump. Kirchner and Dorussen (2020) discussed the agreements from the perspective of security cooperation, stressing the importance of the EU-Japan EPA and SPA as platforms to address regional and global challenges. Gilson (2020) performed an in-depth analysis of the EU-Japan economic and political relations that paved the way to the EPA and SPA during the crisis of multilateralism in international relations.

In the empirical part, the authors attempt to verify two hypotheses:

H1: Trade liberalization under the EU-Japan EPA, including both tariff and non-tariff measures, may contribute to the further expansion of the EU-Japan bilateral trade in the automotive industry.

H2: Mid- and long-term trends in intra-industry trade, including their horizontal and vertical patterns, depend on the competitiveness of the automotive industry and corresponding quality and cost differences.

\section{RESEARCH METHODOLOGY}

A point of reference in the quantitative analysis of intra-industry trade is the Grubel-Lloyd (GL) index, employed in recent studies conducted by, among others, Baccini and Dür (2018), Baccini, Dür, and Elsig (2018), Bobowski (2018), Bagchi and Bhattacharyya (2019), Anderer, Dür, and Lechner (2020), Zarbà, Chinnici, and D'Amico (2020) and Jošić and Žmuk (2020). Abd-el-Rahman (1984) is considered a pioneer of research on intra-industry trade, assuming decomposition into a horizontal and vertical pattern with the use of export and import unit values, further popularised due to research conducted by Greenaway, Hine, and Milner (1994).

In this article we concentrate on the automotive industry, which is important in terms of GDP, employment and R\&D in both the EU and Japan. In this industry there is a potential for intra-industry trade in both horizontal and vertical patterns due to the decomposition of motor vehicles into various parts and components. This decomposition, in turn, enhances the fragmentation and spatial dispersion of production processes. Automotive manufacturing is characterised by high technology and long value chains, as well as the involvement of multinational enterprises (MNEs).

The analytical part of the article consists of three stages using each of the UN Comtrade databases. In the first stage of the analysis, we studied bilateral trade in goods between the EU-28 (as the statistical analysis covers the period 2010-2019, the UK is considered as the member of the EU) and Japan in the years 2010-2019, disaggregating them into two- and four-digit HS codes to identify statistically relevant codes. In the second stage, we disaggregated trade flows into six-digit HS codes to identify dominant codes in the automotive industry selected as the case study. In the third stage of the analysis, we calculated Grubel-Lloyd and Balassa indexes to indicate the dominant patterns of intra-industry trade in each of the selected six-digit codes in the automotive industry over the whole ten-year period, including disaggregation to high- and low-quality vertical intra-industry trade.

To analyse the patterns of intra-industry trade in the automotive industry, we selected 65 six-digit HS codes classified into 15 groups (Table 1 ). 
Table 1. The six-digit HS codes selected for analysis of the automotive industry

\begin{tabular}{|c|c|c|c|}
\hline Group of codes & Six-digit HS codes & Group of codes & Six-digit HS codes \\
\hline I Rubber & $\begin{array}{c}401110,401120,401220, \\
401290,401310\end{array}$ & II Glass & $700711,700721,700910$ \\
\hline III Metal & 830120,830230 & IV Engines & $\begin{array}{c}840731,840732,840733,840734, \\
840790,840820\end{array}$ \\
\hline V Engine parts & $\begin{array}{c}840991,840999,841330, \\
842123,842131,842542\end{array}$ & VI Machinery & $\begin{array}{c}848310,848320,848330,848340, \\
848350,848360,848390\end{array}$ \\
\hline \multirow{2}{*}{ VII Electric } & $\begin{array}{c}850710,850720,850730, \\
850740,850780,851220, \\
851230,851240,851290, \\
851829,852721,852729, \\
853921,853929,854430\end{array}$ & VIII Chassis fitted & 870600 \\
\hline IX Vehicle bodies & 870710 & & $870810,870821,870829$ \\
\hline XI Transmissions & 870840 & X Vehicle parts & $870850,870870,870880,870891$, \\
\hline XIII Clocks & 910400 & XII Vehicles & $870892,870893,870894,870899$ \\
\hline \multirow{2}{*}{ XV Automobiles } & $\begin{array}{c}870321,870322,870323, \\
870324,870331,870332,\end{array}$ & XIV Seats & 940120,940190 \\
\hline
\end{tabular}

Source: original compilation based on the UN Comtrade Database (2020).

The quantitative analysis of intra-industry trade in the automotive industry in the years 2010-2019 was performed using the Grubel-Lloyd Index according to the following formula (Grubel \& Lloyd, 1971):

where:

$$
\begin{gathered}
G L_{i}=\frac{\left(x_{i}+m_{i}\right)-\left|x_{i}-m_{i}\right|}{x_{i}+m_{i}}=1-\frac{\left|x_{i}-m_{i}\right|}{x_{i}+m_{i}} \\
0 \leq G L_{i} \leq 1
\end{gathered}
$$

$x_{i}$ - the export value of industry $i$

$m_{i}$ - the import value of industry $i$;

When the GL index equals 1 , it indicates a perfect balance between the imports and exports. On the other hand, a GL index of 0 indicates no intra-industry trade, which makes a given industry either import- or export-competing, but never both. The higher the GL index, the higher the share of intraindustry trade in total trade.

Trade regionalism may serve as a trigger of inter-industrial reallocation. As a result, competitive industries expand, whereas those that are non-competitive erode.

Greenaway, Hine, and Milner (1994) transformed the Grubel-Lloyd index from formula (1), distinguishing between horizontal and vertical patterns of intra-industry trade (2). In the latter case, however, additional disaggregation with respect to the relative quality of export of a given product compared to its import is made.

$$
G L_{i}=1-\frac{\left|x_{i}^{h}-m_{i}^{h}\right|+\left|x_{i}^{v l}-m_{i}^{v l}\right|+\left|x_{i}^{v h}-m_{i}^{v h}\right|}{x_{i}+m_{i}}
$$

where:

$x_{i}^{h}$ - the export value of the horizontal pattern of industry $i$;

$m_{i}^{h}$ - the import value of the horizontal pattern of industry $i$;

$x_{i}^{v l}$ - the export value of the low-quality vertical pattern of industry $i$;

$m_{i}^{v l}$ - the import value of the low-quality vertical pattern of industry $l$;

$x_{i}^{v h}$ - the export value of the high-quality vertical pattern of industry $l$;

$m_{i}^{v h}$ - the import value of the high-quality vertical pattern of industry $i$; 
We adapted the Balassa index to measure horizontal and vertical intra-industry trade (HIIT and VIIT) indexes (3).

$$
H B=\frac{\sum_{i=1}^{N_{1}}\left[\left(x_{i}+m_{i}\right)-\left|x_{i}-m_{i}\right|\right]}{\sum_{i=1}^{N}\left(x_{i}+m_{i}\right)}, \quad V B=\frac{\sum_{i=1}^{N_{2}}\left[\left(x_{i}+m_{i}\right)-\left|x_{i}-m_{i}\right|\right]}{\sum_{i=1}^{N}\left(x_{i}+m_{i}\right)}
$$

where $N_{1}$ indicates six-digit codes of industry $i$ that exhibit HIIT, $N_{2}$ indicates six-digit codes of industry $i$ that exhibit VIIT and $N$ indicates a total number of six-digit codes of industry $i$, according to the following equation: $B_{i}=H B_{i}+V B_{i}$

Our analysis involves HIIT and VIIT measures as established by Fontagné and Freudenberg (1997). The horizontal pattern of intra-industry trade is recognised as dominant when the similarity criterion is met. Then, the differences between the unit values of exports $\left(U V_{i}^{x}\right)$ and imports $\left(U V_{i}^{m}\right)$ are small (4).

$$
\frac{1}{(1+\dot{\alpha})} \leq \frac{U V_{i}^{x}}{U V_{i}^{m}} \leq 1+\dot{\alpha}
$$

To differentiate the product quality, we calculated export and import unit values (5)(6):

$$
\begin{aligned}
U V_{i}^{x} & =\frac{x_{i}}{Q x_{i}} \\
U V_{i}^{m} & =\frac{m_{i}}{Q m_{i}}
\end{aligned}
$$

where $Q x_{i}$ is the quantity of exports of industry $i$ and $Q m_{i}$ is the quantity of imports of industry $i$.

The vertical pattern of intra-industry trade involves either higher quality exports compared to the corresponding imports, which translates into a significantly higher unit value of exports than imports (7), or lower quality exports compared to corresponding imports, which translates into significantly lower unit values of exports than imports (8).

$$
\begin{aligned}
& \frac{U V_{i}^{x}}{U V_{i}^{m}}<\frac{1}{(1+\dot{\alpha})} \\
& \frac{U V_{i}^{x}}{U V_{i}^{m}}>1+\alpha^{\prime}
\end{aligned}
$$

Formally, $U V_{i}^{x}$ is the unit value of the exports of industry $i$ at the six-digit level, and $U V_{i}^{m}$ is the unit value of the imports of industry $i$ at the six-digit level. Both 0.85 and 1.15 thresholds result in the adoption of a dispersion factor $\alpha$ equal to 0.15 (whereas some authors select 0.25 ). In the case of the vertical differentiation of products, low-quality vertical products are traded when the relative unit value of the exports-to-imports ratio is lower than $(1-\alpha)$, or 0.85 , whereas trade in high-quality vertical products results in a relative unit value of exports-to-imports ratio higher than $(1+\alpha)$, or 1.15.

\section{RESULTS AND DISCUSSION}

\section{The automotive industry in the EU and Japan}

The automotive industry contributes significantly to the economies of the EU and Japan. In 2019, the automotive industry in the EU and Japan accounted for 6.1 and $8.2 \%$ of total jobs, respectively, 28 and $24.5 \%$ of total private R\&D expenditures, and 7 and $12 \%$ of GDP (Table 2 ).

Table 2. The automotive industry in the economies of the EU and Japan, 2019

\begin{tabular}{|c|c|c|c|c|c|}
\hline Country & $\begin{array}{c}\text { Employment (mil- } \\
\text { lions of employees) }\end{array}$ & $\begin{array}{c}\text { Share of total } \\
\text { employment (\%) }\end{array}$ & $\begin{array}{c}\text { R\&D expenditures } \\
\text { (billions of USD) }\end{array}$ & $\begin{array}{c}\text { Share of total private } \\
\text { R\&D expenditures (\%) }\end{array}$ & $\begin{array}{c}\text { Share of } \\
\text { GDP (\%) }\end{array}$ \\
\hline EU & 13.8 & 6.1 & 57.4 & 28 & 7 \\
\hline Japan & 5.46 & 8.2 & 27.66 & 24.5 & 12 \\
\hline
\end{tabular}

Source: original compilation based on ACEA (2020); JAMA (2020).

The EU and Japan each play an important role in the global automotive industry. Both national industries comprise significant shares of the total volume and value of production and international trade in autos and their parts and equipment, with special regard to passenger cars. According to data 
provided by the European Automobile Manufacturers' Association (ACEA), which combine commercial vehicle production in Japan and the Republic of Korea, in 2019, the combined production of passenger cars in the EU and Japan amounted to 23.96 million units (32.33\% of the global volume); the countries produced 4.2 million units of (primarily light) commercial vehicles ( $22.46 \%$ of the global volume). The shares of commercial vehicles of all types (light, medium and heavy) of total motor vehicle production were comparable in the EU and Japan in 2019: 14.6 and 14.1\%, respectively (ACEA, 2020; JAMA, 2019).

Japan is the home country to such car brands as Toyota, Suzuki, Honda, Daihatsu, Nissan, Mazda and Mitsubishi, while the EU has produced Volkswagen, Renault, Peugeot, Citroën, Volvo, BMW and Mercedes. In 2019, among the top ten auto brands in terms of the global market share, three were Japanese - Toyota (10.24\%), Honda (5.46\%) and Nissan (5.15\%) - and three were from the EU: Volkswagen (7.59\%), Mercedes (2.94\%) and BMW (2.62\%; Statista, 2020b). The annual reports published by ACEA provide abundant data on the automotive industry, including production volume, trade and investments. According to the available data, in 2014-2017 the global production volume of passenger cars increased by $10.89 \%$ to 79.88 million units. However, the volume declined over the two subsequent years by $7.23 \%$ to 74.11 million units (Table 3). Importantly, the EU-28's share of global volume increased over the last two years to $21.28 \%$ and is thus slightly below its 2015 peak. The highest volume of production in the EU, 16.93 million units, was recorded in 2016.

Table 3. Production of passenger cars in the EU and Japan in units (share in the global volume, \%), 2014-2019

\begin{tabular}{|c|c|c|c|c|c|c|}
\hline Country & $\mathbf{2 0 1 4}$ & $\mathbf{2 0 1 5}$ & $\mathbf{2 0 1 6}$ & $\mathbf{2 0 1 7}$ & $\mathbf{2 0 1 8}$ & $\mathbf{2 0 1 9}$ \\
\hline EU & 14952696 & 16030126 & 16925471 & 16493027 & 16644609 & 15769041 \\
& $(20.76)$ & $(21.77)$ & $(21.74)$ & $(20.65)$ & $(21.04)$ & $(21.28)$ \\
\hline Germany & 5446423 & 5532675 & 5746808 & 5448171 & 5120409 & 4661328 \\
& $(7.56)$ & $(7.51)$ & $(7.38)$ & $(6.82)$ & $(6.47)$ & $(6.29)$ \\
\hline Spain & 1851828 & 2175612 & 2354117 & 2197064 & 2168877 & 2175909 \\
& $(2.57)$ & $(2.95)$ & $(3.02)$ & $(2.75)$ & $(2.74)$ & $(2.94)$ \\
\hline United King- & 1529233 & 1588631 & 1722698 & 1677594 & 1519440 & 1303135 \\
dom & $(2.12)$ & $(2.16)$ & $(2.21)$ & $(2.1)$ & $(1.92)$ & $(1.76)$ \\
\hline France & 1455160 & 1504913 & 1565951 & 1661499 & 1772641 & 1675198 \\
& $(2.02)$ & $(2.04)$ & $(2.01)$ & $(2.08)$ & $(2.24)$ & $(2.26)$ \\
\hline Czech Re- & 1131247 & 1225861 & 1344182 & 1397916 & 1437396 & 1427563 \\
public & $(1.57)$ & $(1.66)$ & $(1.73)$ & $(1.75)$ & $(1.82)$ & $(1.93)$ \\
\hline Japan & 8169024 & 7759655 & 7762054 & 8218436 & 8214183 & 8187935 \\
& $(11.34)$ & $(10.54)$ & $(9.97)$ & $(10.29)$ & $(10.38)$ & $(11.05)$ \\
\hline China & 17473310 & 18977727 & 22555454 & 23638856 & 22726556 & 20675662 \\
& $(24.26)$ & $(25.77)$ & $(28.98)$ & $(29.59)$ & $(28,72)$ & $(27.9)$ \\
\hline United & 9041649 & 9260326 & 9127015 & 8030633 & 8028375 & 7452191 \\
States & $(12.55)$ & $(12.58)$ & $(11.73)$ & $(10.05)$ & $(10.15)$ & $(10.06)$ \\
\hline World & 72039656 & 73637407 & 77839234 & 79884806 & 79126247 & 74107368 \\
& $(100.0)$ & $(100.0)$ & $(100.0)$ & $(100.0)$ & $(100.0)$ & $(100.0)$ \\
\hline
\end{tabular}

Source: original compilation based on ACEA (2016, pp. 8-10); ACEA (2017, pp. 14-16); ACEA (2018, pp. 11-13); ACEA (2019, pp. 12-14); ACEA (2020, pp. 9-11).

Among the EU member states, Germany maintained its leading position as a manufacturer of passenger cars. However, German production volume trended downward since 2017, falling to 4.66 million units in 2019 (the production share declined from 7.38 to 6.29\%). Moreover, the share of Germany in the global production volume gradually decreased through the study period irrespective of the upward trend in German production between 2014 and 2016. Spain, the second-largest producer of passenger cars in the EU, recorded a comparable share of $3 \%$ of the global volume in years 2015-2016 and 2019, with the strongest upward trend in production volume in the period 20142015 (by more than 320 thousand units). The United Kingdom occupied the third position among EU producers until 2017, with a downward trend in terms of the share in the global volume of production since 2016 (production volume dropped by more than 400 thousand units in three years). In 
2018 it lost its position in favour of France ( $2.24 \%$ share in the global volume of production), and a year later was also overtaken by the Czech Republic (1.93\%).

Japan's share in the global volume of passenger car production decreased by $0.29 \%$ over the study period. However, the number of units manufactured in the years 2014 and 2017-2019 were comparable and varied from 8.17 to 8.21 million. The EU and Japan's The combined share of the EU and Japan in the global volume of production did not change considerably between 2014 and 2019, increasing by $0.23 \%$, with the lowest score recorded in 2017 (30.94) and the highest in 2019 (32.33).

Importantly, the share of China, the leading global manufacturer, increased considerably between 2014 and 2017 to $29.59 \%$. China's share declined slightly over the next two years to $27.9 \%$, which translated into a reduction of 2.96 million units (meanwhile, the combined EU-Japan volume of production decreased by over 750 thousand units). In 2014, the EU-Japanese share exceeded that of China by $7.84 \%$ or 5.65 million units, and five years later, by $4.43 \%$ or 3.28 million units.

The top export markets for EU passenger cars in terms of value in the study period were the United States and China. Japan constantly improved its position through the years and occupied the third position since 2017, with cars valued more than USD 8 billion exported annually from the EU (Table 4). In terms of the number of units exported, the United States maintained its leading position in the period 2014-2019. However, both China and Japan were ranked at lower positions in the first three years when compared to their export rank in terms of value. With more than 263 thousand passenger cars, Japan was the third-largest export market for the EU only in 2019. Interestingly, between 2014 and 2019, the number of EU passenger cars exported to China declined by over 149 thousand units (to less than 460 thousand) with a downward trend since 2017, while in the case of Japan there was a slight upward trend in the period 2014-2018 and a small decline a year later.

Meanwhile, Japan maintained its position as the largest import market of EU passenger cars in terms of value with an upward trend over the whole period. Increasing from USD 6.6 billion to USD 11.7 billion, Japan expanded its advantage over the United States, the second-largest import market. In terms of volume, Japan was ranked second after Turkey. Moreover, Japan recorded an upward trend over the whole period, while imports from Turkey slightly diminished after 2017. As a consequence, while the EU imported 145 thousand more passenger cars from Turkey than from Japan in 2017, two years later the difference in favour of Turkey diminished to only 4 thousand units.

The volume of overseas vehicle production by Japan increased since 2010 by $43.18 \%$ to 18.9 million units in 2019. Of these units, 1.22 million were manufactured in the EU (10.85 million in Asia, 4.4 million in North America and 1.75 million in Latin America). As Tsukamoto (2006) pointed out, while Japan produces high-technology automotive parts on its own, several Southeast Asian locations compose a complementary production network. For instance, Thailand manufactures diesel engines, steering columns and finished cars; the Philippines manufactures transmissions and front-wheel drive shafts; Malaysia produces engine computers and steering links and Indonesia builds gasoline engines and transmissions.

Among the ten best-selling automotive producers in Japan in 2019, there were only native brands. The European brands Mercedes Benz, Volkswagen and BMW were ranked 11th, 13th and 15th, respectively (Bekker, 2020).

From the perspective of the EU, Japan is neither among the top ten export nor import partners in trade in commercial vehicles (light commercial vehicles up to five tonnes and commercial vehicles over five tonnes, including buses and coaches). Therefore, this article focuses on passenger cars. As passenger cars account for more than $85 \%$ of the total motor vehicle production in both the EU and Japan, the impact of the EPA is likely more tangible on this area of the industry.

According to the ACEA's data, there are 298 automotive assembly and engine production plants in Europe, of which 196 are located in the EU and the United Kingdom. The countries with the most automotive plants are Germany (42), France (31), the United Kingdom (30), Italy (23), Spain (17) and Poland (16). Most of the $91 \mathrm{EU}$ plants producing cars are located in Germany (25), France (13) and Italy (11). Of the 55 plants producing automotive engines, 12 are located in Germany, eight in Italy, six in Poland and five in Sweden (ACEA, 2020). Importantly, ACEA does not include information on smaller-sized suppliers and producers of automotive parts, as well as plants specialising in manufacturing non-engine parts. 
Table 4. Top five destinations for EU exports and imports of passenger cars in value and volume, 2014-2019

\begin{tabular}{|c|c|c|c|c|c|c|c|c|c|c|c|}
\hline \multicolumn{2}{|c|}{2014} & \multicolumn{2}{|c|}{2015} & \multicolumn{2}{|c|}{2016} & \multicolumn{2}{|c|}{2017} & \multicolumn{2}{|c|}{2018} & \multicolumn{2}{|c|}{2019} \\
\hline \multicolumn{12}{|c|}{ Exports in value (millions of USD) } \\
\hline United States & 29779 & United States & 40466 & United States & 37721 & United States & 38344 & United States & 37242 & United States & 37631 \\
\hline China & 23492 & China & 17948 & China & 19741 & China & 22337 & China & 22311 & China & 21734 \\
\hline Switzerland & 6375 & Switzerland & 7620 & Switzerland & 7772 & Japan & 8172 & Japan & 8408 & Japan & 8247 \\
\hline Turkey & 5133 & Turkey & 7454 & Japan & 7340 & Switzerland & 7432 & Switzerland & 7044 & Switzerland & 7494 \\
\hline $\begin{array}{l}\text { Republic } \\
\text { of Korea }\end{array}$ & 4693 & Japan & 6465 & Turkey & 7333 & Turkey & 6544 & $\begin{array}{l}\text { Republic } \\
\text { of Korea }\end{array}$ & 6965 & $\begin{array}{l}\text { Republic } \\
\text { of Korea }\end{array}$ & 6131 \\
\hline \multicolumn{12}{|c|}{ Exports in volume } \\
\hline United States & 998520 & United States & 1223025 & United States & 1170634 & United States & 1176841 & United States & 1154784 & United States & 1040770 \\
\hline Turkey & 372753 & Turkey & 531726 & Turkey & 534181 & China & 575286 & China & 543643 & China & 459623 \\
\hline China & 608912 & China & 469755 & China & 531336 & Turkey & 466575 & Turkey & 290627 & Japan & 263057 \\
\hline Switzerland & 270741 & Switzerland & 303127 & Switzerland & 282473 & Japan & 281749 & Japan & 285434 & Switzerland & 258195 \\
\hline Japan & 236833 & Japan & 247837 & Japan & 279197 & Switzerland & 275097 & Switzerland & 261982 & Turkey & 224240 \\
\hline \multicolumn{12}{|c|}{ Imports in value (millions of USD) } \\
\hline Japan & 6685 & Japan & 7719 & Japan & 9142 & Japan & 9709 & Japan & 9902 & Japan & 11695 \\
\hline United States & 4911 & United States & 6944 & United States & 7230 & Turkey & 8579 & Turkey & 8802 & United States & 9424 \\
\hline Turkey & 4363 & Turkey & 5056 & Turkey & 6414 & $\begin{array}{l}\text { Republic } \\
\text { of Korea }\end{array}$ & 6585 & $\begin{array}{l}\text { Republic } \\
\text { of Korea }\end{array}$ & 7180 & Turkey & 8916 \\
\hline $\begin{array}{l}\text { Republic } \\
\text { of Korea }\end{array}$ & 4009 & $\begin{array}{l}\text { Republic } \\
\text { of Korea }\end{array}$ & 4330 & $\begin{array}{l}\text { Republic } \\
\text { of Korea }\end{array}$ & 4812 & United States & 6420 & United States & 5539 & $\begin{array}{l}\text { Republic } \\
\text { of Korea }\end{array}$ & 7866 \\
\hline South Africa & 1208 & South Africa & 2400 & Mexico & 2212 & Mexico & 4723 & Mexico & 5248 & Mexico & 4963 \\
\hline \multicolumn{12}{|c|}{ Imports in volume } \\
\hline Turkey & 472768 & Turkey & 526499 & Turkey & 646119 & Turkey & 789502 & Turkey & 784937 & Turkey & 764703 \\
\hline Japan & 438638 & Japan & 479795 & Japan & 577704 & Japan & 644695 & Japan & 679524 & Japan & 760717 \\
\hline $\begin{array}{l}\text { Republic } \\
\text { of Korea }\end{array}$ & 347842 & $\begin{array}{l}\text { Republic } \\
\text { of Korea }\end{array}$ & 374769 & $\begin{array}{l}\text { Republic } \\
\text { of Korea }\end{array}$ & 402935 & $\begin{array}{l}\text { Republic } \\
\text { of Korea }\end{array}$ & 519136 & $\begin{array}{l}\text { Republic } \\
\text { of Korea }\end{array}$ & 540732 & $\begin{array}{l}\text { Republic } \\
\text { of Korea }\end{array}$ & 537341 \\
\hline United States & 235009 & United States & 242027 & United States & 254806 & Morocco & 240908 & Morocco & 283622 & United States & 358044 \\
\hline Morocco & 152588 & Morocco & 169822 & Morocco & 196738 & Mexico & 235533 & United States & 267515 & Morocco & 292148 \\
\hline
\end{tabular}

Source: original compilation based on: ACEA (2016, pp. 12-13); ACEA (2017, pp. 18-19); ACEA (2018, pp. 15-16); ACEA (2019, pp. 16-17); ACEA (2020, pp. 13-14). 
Table 5 presents the key locations of Japanese manufacturers of passenger cars and engines in the EU and the United Kingdom. Toyota Motor Europe produces engines in Poland, France and the United Kingdom; light commercial vehicles in Portugal and passenger cars in France and the Czech Republic. In this last case, the engines are produced under a joint venture with PSA (Toyota Peugeot Citroën Automobile - TPCA). The Nissan Motor Company produces engines and passenger cars in the United Kingdom and Spain, in the latter country light commercial vehicles are manufactured as well. Honda produces engines and passenger cars in the United Kingdom, while Suzuki produces passenger cars in Hungary.

Table 5. Automotive plants of Japanese companies in the EU and the United Kingdom, 2020

\begin{tabular}{|c|c|c|c|}
\hline Company & Location & Specialisation & Brand(s) \\
\hline Toyota Motor Europe & Deeside, United Kingdom & engines & Toyota \\
\hline Toyota Motor Europe & $\begin{array}{c}\text { Onnaing (Valenciennes), } \\
\text { France }\end{array}$ & engines and passenger cars & Toyota \\
\hline Toyota Motor Europe & Walbrzych, Poland & engines & Toyota \\
\hline Toyota Motor Europe & Jelcz-Laskowice, Poland & engines & Toyota \\
\hline Toyota Motor Europe & Ovar, Portugal & light commercial vehicles & Toyota \\
\hline $\begin{array}{c}\text { TPCA Toyota Motor Corp } \\
- \text { PSA }\end{array}$ & Kolin, Czech Republic & passenger cars & Citroën \\
\hline Nissan Motor Company & Sunderland, United Kingdom & engines and passenger cars & Nissan, Nissan Electric \\
\hline $\begin{array}{c}\text { Nissan Motor Company } \\
\text { Honda }\end{array}$ & Barcelona, Spain & $\begin{array}{c}\text { engines, passenger cars and } \\
\text { light commercial vehicles }\end{array}$ & Nissan, Renault \\
\hline Suzuki & Swindon, United Kingdom & engines and passenger cars & Honda \\
\hline
\end{tabular}

Source: original compilation based on ACEA (2020a).

There are very few examples of collaboration between the EU and Japanese automotive enterprises in Japan so far. These include Mitsubishi Motors-Daimler AG in Kanagawa (Fuso trucks and buses) and Renault-Nissan Motor Company-Mitsubishi Motors in Okasaki (passenger cars). The Mitsubishi Fuso Truck and Bus Corporation was established in 2003, and its headquarters were relocated from Tokyo to Kanagawa three years later. Daimler AG currently holds $89.29 \%$ of the company shares, while Mitsubishi Motors remains a minor shareholder. The second alliance was formed in 1999 by Renault and Nissan. The former owns $43 \%$ of shares in Nissan, while Nissan owns $15 \%$ of shares in Renault and 34\% of shares in Mitsubishi, which joined this alliance in 2016 (Warner, 2019).

\section{Intra-industry trade and the EPA}

Japan is the seventh-largest trade partner of the EU and the second-largest in Asia, after China. Total trade between the EU and Japan amounted to, on average, USD 147.7 billion annually in the years 2010-2019, with the highest level recorded in 2011 (USD 165.1 billion). Trade volume followed a downward trend until 2015 (falling to USD 127.9 billion) and an upward trend from then until 2019 (reaching USD 157.2 billion). The EU-28-Japan trade in goods has traditionally been marked by a deficit on the EU side, and this rule was confirmed in the study period. However, Japan's surplus diminished through the years from USD 31.42 billion in 2010 to USD 7.44 billion in 2019, mainly due to an increase in the EU exports, accompanied by a slight decrease in imports from Japan (Figure 1). In 2013-2015, EU-28Japan trade relations were the closest to balance, with the deficit on the EU side ranging from USD 4.25-4.89 billion. Importantly, since 2015, there was an upward trend in the value of the EU exports to Japan, with the highest level recorded in 2019 (USD 74.9 billion), while imports from Japan reached a peak in 2011 (USD 97.83 billion).

The EU-28-Japan trade in goods was dominated by the same five two-digit HS codes through the whole study period: 84 (nuclear reactors, boilers, machinery and mechanical appliances; parts thereof), 87 (vehicles other than railway or tramway rolling stock, and parts and accessories thereof), 90 (optical, photographic, cinematographic, measuring, checking, precision, medical or surgical instruments and apparatus; parts and accessories thereof) in exports and imports, as well as 30 (pharmaceutical products) in exports and 85 (electrical machinery and equipment and parts thereof; sound 
recorders and reproducers, television image and sound recorders and reproducers and parts and accessories of such articles) in imports (Table 6).
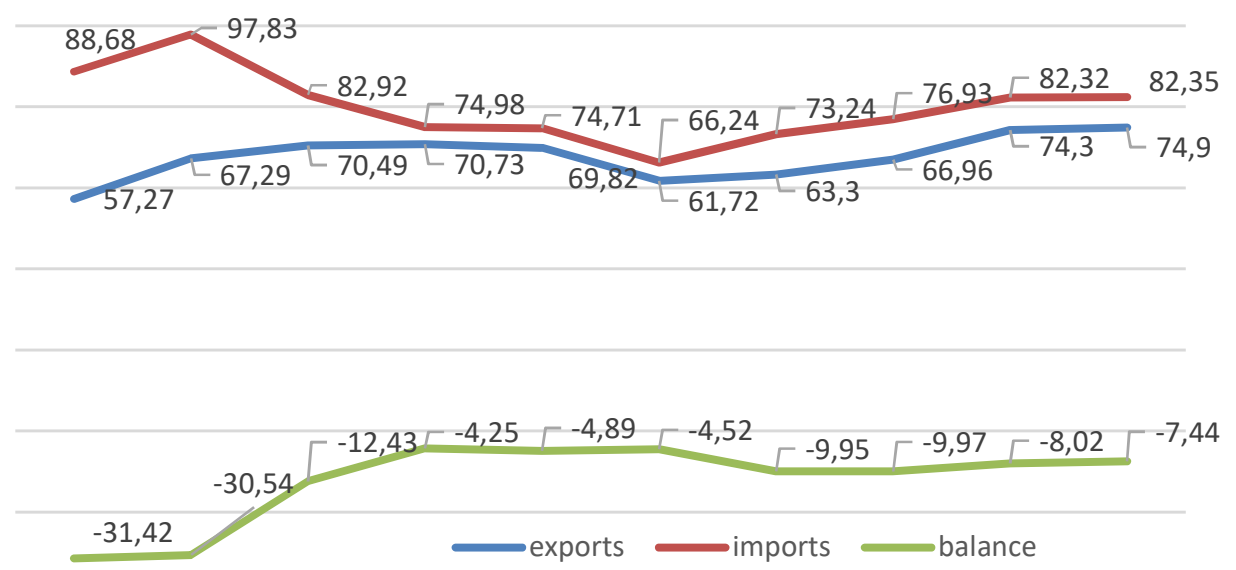

Figure 1. The EU-28-Japan trade in goods in total, 2010-2019 (billions of USD) Source: original calculations based on the UN Comtrade Database (2020).

Table 6. The dominant two-digit HS codes in the EU-28-Japan trade in goods, 2010-2019 (USD)

\begin{tabular}{|c|c|c|c|c|c|c|c|}
\hline \multicolumn{4}{|c|}{ Exports } & \multicolumn{4}{|c|}{ Imports } \\
\hline HS code & Nominal value & HS code & Nominal value & HS code & Nominal value & HS code & Nominal value \\
\hline \multicolumn{2}{|r|}{2010} & 2011 & & \multicolumn{2}{|r|}{2010} & \multicolumn{2}{|r|}{2011} \\
\hline 87 & 7009963345 & 87 & 9185990649 & 84 & $\mid 22737915097$ & 84 & 26079341717 \\
\hline 30 & 6992880218 & 84 & 8551226177 & 85 & 17944099189 & 87 & 18726014407 \\
\hline 84 & 6984719172 & 30 & 8467465659 & 87 & 17216635429 & 85 & 18303209486 \\
\hline 90 & 5666338359 & 90 & 5993610403 & 90 & 7147428198 & 90 & 8040135823 \\
\hline \multicolumn{2}{|r|}{2012} & \multicolumn{2}{|r|}{2013} & \multicolumn{2}{|r|}{2012} & \multicolumn{2}{|r|}{2013} \\
\hline 87 & 10288120301 & 87 & 10883096042 & 84 & 22734999861 & 84 & 21182712399 \\
\hline 30 & 9406647768 & 30 & 9604654452 & 87 & 15646472845 & 87 & 14323386027 \\
\hline 84 & 8163252641 & 84 & 8512127352 & 85 & 15304482723 & 85 & 13782774292 \\
\hline 90 & 6701633767 & 90 & 6346029413 & 90 & 7172500324 & 90 & 6413810228 \\
\hline \multicolumn{2}{|r|}{2014} & \multicolumn{2}{|r|}{2015} & \multicolumn{2}{|r|}{2014} & \multicolumn{2}{|r|}{2015} \\
\hline 87 & 10548050945 & 30 & 9851618348 & 84 & 21403105419 & 84 & 17712889137 \\
\hline 84 & 9612750220 & 87 & 9301188707 & 87 & 14428308195 & 87 & 13860681861 \\
\hline 30 & 8518700043 & 84 & 8332827726 & 85 & 13475159594 & 85 & 11455219116 \\
\hline 90 & 6255456551 & 90 & 5285050284 & 90 & 6474115380 & 90 & 5699975894 \\
\hline \multicolumn{2}{|r|}{2016} & \multicolumn{2}{|r|}{2017} & \multicolumn{2}{|r|}{2016} & \multicolumn{2}{|r|}{2017} \\
\hline 87 & 10348260552 & 87 & 11744678044 & 84 & 17719669574 & 84 & 19515698153 \\
\hline 30 & 9387257061 & 84 & 9001775055 & 87 & 16400856678 & 87 & 17579284487 \\
\hline 84 & 8207640207 & 30 & 8926128405 & 85 & 11749820640 & 85 & 12426305527 \\
\hline 90 & 5668231397 & 90 & 6117792554 & 90 & 5827897489 & 90 & 6065120001 \\
\hline \multicolumn{2}{|r|}{2018} & \multicolumn{2}{|r|}{2019} & \multicolumn{2}{|r|}{2018} & \multicolumn{2}{|r|}{2019} \\
\hline 87 & 12640990324 & 87 & 11636062000 & 84 & 20918926530 & 87 & 20391060044 \\
\hline 84 & 10463441064 & 84 & 10104553916 & 87 & 19025040542 & 84 & 19521640031 \\
\hline 30 & 9925093046 & 30 & 9844985853 & 85 & 13471104894 & 85 & 12680551151 \\
\hline 90 & 6730420187 & 90 & 6624348704 & 90 & 6565945578 & 90 & 6511100152 \\
\hline
\end{tabular}

Source: original calculations based on the UN Comtrade Database (2020).

Disaggregation into four-digit HS codes indicated the prevalence of 8703 (motor cars and other motor vehicles principally designed for the transport of fewer than 10 persons, including station wagons and racing cars, excluding motor vehicles) and 8708 (parts and accessories for tractors, motor vehicles for the 
transport of 10 or more persons, motor cars and other motor vehicles principally designed for the transport of persons, motor vehicles for the transport of goods and special-purpose motor vehicles) in exports and imports, except for year 2014 in the case of exports (Table 7). However, the four-digit HS codes of Chapter 84 differed in the case of exports and imports. For exports, 8408 (compression-ignition internal combustion piston engine; diesel or semi-diesel engine) and 8411 (turbojets, turbopropellers and other gas turbines) dominated. For imports, 8429 (self-propelled bulldozers, angledozers, graders, levellers, scrapers, mechanical shovels, excavators, shovel loaders, tamping machines and roadrollers) and 8443 (printing machinery, parts and components thereof) were the most common codes.

Table 7. The dominant four-digit HS codes in the EU-28-Japan trade in goods, 2010-2019 (millions of USD)

\begin{tabular}{|c|c|c|c|c|c|c|c|}
\hline \multicolumn{4}{|c|}{ Exports } & \multicolumn{4}{|c|}{ Imports } \\
\hline HS code & Nominal value & HS code & Nominal value & HS code & Nominal value & HS code & Nominal value \\
\hline \multicolumn{2}{|r|}{2010} & \multicolumn{2}{|r|}{2011} & \multicolumn{2}{|r|}{2010} & \multicolumn{2}{|r|}{2011} \\
\hline 8703 & 5094.2 & 8703 & 7084.95 & 8703 & 10026.61 & 8703 & 10442.75 \\
\hline 8708 & 1390.57 & 8708 & 1482.39 & 8708 & 4428.37 & 8708 & 5484.18 \\
\hline 8411 & 715.69 & 8411 & 978.17 & 8471 & 1525.95 & 8414 & 2004.51 \\
\hline 8486 & 611.06 & 8486 & 964.44 & 8407 & 1081.4 & 8429 & 1609.23 \\
\hline \multicolumn{2}{|r|}{2012} & \multicolumn{2}{|r|}{2013} & \multicolumn{2}{|r|}{2012} & \multicolumn{2}{|r|}{2013} \\
\hline 8703 & 8108.5 & 8703 & 8502.88 & 8703 & 8068.59 & 8703 & 7850.6 \\
\hline 8708 & 1470.62 & 8708 & 1640.6 & 8708 & 5039.41 & 8708 & 4285.64 \\
\hline 8411 & 1201.61 & 8411 & 1582.37 & 8443 & 4462.99 & 8443 & 4217.87 \\
\hline 8408 & 721.04 & 8408 & 635.28 & 8414 & 1661.99 & 8411 & 1646.39 \\
\hline \multicolumn{2}{|r|}{2014} & \multicolumn{2}{|r|}{2015} & \multicolumn{2}{|r|}{2014} & \multicolumn{2}{|r|}{2015} \\
\hline 8703 & 7960.14 & 8703 & 7165 & 8703 & 8861.24 & 8703 & 8570.17 \\
\hline 8411 & 1813.19 & 8708 & 1505.52 & 8708 & 3380.1 & 8708 & 3326.49 \\
\hline 8708 & 1811.75 & 8411 & 1401.91 & 8429 & 1838.61 & 8429 & 1596.66 \\
\hline 8408 & 922.28 & 8408 & 914.69 & 8411 & 1703.77 & 8411 & 1281.3 \\
\hline \multicolumn{2}{|r|}{2016} & \multicolumn{2}{|r|}{2017} & \multicolumn{2}{|r|}{2016} & \multicolumn{2}{|r|}{2017} \\
\hline 8703 & 8119.13 & 8703 & 9243.74 & 8703 & 10136.87 & 8703 & 10959.51 \\
\hline 8708 & 1529.02 & 8708 & 1753.57 & 8708 & 4231.75 & 8708 & 4361.77 \\
\hline 8408 & 944.26 & 8408 & 855.21 & 8443 & 2354.25 & 8443 & 2305.69 \\
\hline 8479 & 411.28 & 8486 & 416.17 & 8429 & 1606 & 8429 & 1978.46 \\
\hline \multicolumn{2}{|r|}{2018} & \multicolumn{2}{|r|}{2019} & \multicolumn{2}{|r|}{2018} & \multicolumn{2}{|r|}{2019} \\
\hline 8703 & 9915.28 & 8703 & 9233.75 & 8703 & 11707.03 & 8703 & 13092.79 \\
\hline 8708 & 1929.06 & 8708 & 1553.74 & 8708 & 4684.36 & 8708 & 4674.79 \\
\hline 8408 & 729.1 & 8411 & 1802.31 & 8429 & 2462.08 & 8429 & 2565.27 \\
\hline 8486 & 623.28 & 8408 & 729.94 & 8443 & 2190.84 & 8443 & 1874.9 \\
\hline
\end{tabular}

Source: original calculations based on the UN Comtrade Database (2020).

The GL index in the automotive industry reached the highest level (0.71) in 2011. In the years 20142017 , it steadily declined to 0.46 . However, the VIIT index was the highest (0.66) in 2014, reaching its lowest level (0.46) in 2019 (Table 9). Therefore, our industry-level analysis revealed a downward trend in GL and VIIT since 2014 (Table 9). This suggests a slight decrease in the share of intra-industry trade in total trade between the EU and Japan, as well as the increasing dominance of VIIT through the studied decade. Still, our calculations have important limitations due to the aggregation of trade data at the level of the EU, in line with previous studies by, among others, Gabrisch and Segnana (2003). VIIT values ranging between $0.46-0.66$ might wrongly suggest that EU exports are of relatively lower quality, but this is not supported by trade patterns at the product level. Across the whole study period, the horizontal pattern of intra-industry trade was recorded as dominant 57 times (9.83\% of total cases). We removed seven six-digit HS codes from further analysis due to incomplete data, which made the precise estimation of the GL, VIIT and HIIT indexes impossible. Both in 2010 and 2014 HIIT was dominant for nine six-digit codes; in 2011 and 2013 it was dominant for seven codes. HIIT dominated only three codes in 2018 and two in 2019. Across the whole decade, the 870891 code (radiators and parts 
thereof) recorded a dominant horizontal pattern of intra-industry trade seven times; 854430 (wiring sets), 840999 (parts of piston engines) and 401110 (pneumatic tyres) recorded such a pattern four times and 700910 (mirrors), 851230 (electrical equipment), 870850 (drive axles), 870331 and 870390 (passenger motor vehicles) recorded a dominant horizontal pattern three times. For 33 of the 58 selected six-digit HS codes there was no single year with a dominant horizontal pattern (Table 10).

Table 8. The dominant six-digit HS codes and nominal values of the EU-28-Japan trade in the automotive industry as a share of total trade, 2010-2019 (USD, \%)

\begin{tabular}{|c|c|c|c|c|}
\hline \multirow{2}{*}{ Variables } & Total trade & \multicolumn{3}{|c|}{ Automotive industry } \\
\cline { 2 - 5 } & Nominal value & Nominal value & \% of total & Dominant six-digit HS codes \\
\hline Ex10 & 57266328890 & 7766017038 & 13.56 & 870323,870324 \\
\hline Im10 & 88683972599 & 18945570628 & 21.36 & 870332,870323 \\
\hline Ex11 & 67293562296 & 10064398106 & 14.96 & 870323,870324 \\
\hline Im11 & 97834161208 & 21424627820 & 21.90 & 870332,870323 \\
\hline Ex12 & 70486236640 & 11103945609 & 15.75 & 870323,870324 \\
\hline Im12 & 82917047735 & 17554277718 & 21.17 & 870332,870323 \\
\hline Ex13 & 70728980083 & 11739249299 & 16.60 & 870323,870324 \\
\hline Im13 & 74975542155 & 15748906777 & 21.01 & 870332,870323 \\
\hline Ex14 & 69818135572 & 11702812081 & 16.76 & 870323,870324 \\
\hline Im14 & 74712751419 & 15838414614 & 21.20 & 870332,870323 \\
\hline Ex15 & 61723935939 & 10357427612 & 16.78 & 870323,870324 \\
\hline Im15 & 66242015204 & 14984830276 & 22.62 & 870323,870332 \\
\hline Ex16 & 63296260107 & 11476881124 & 18.13 & 870323,870324 \\
\hline Im16 & 73243935224 & 17583345011 & 24.01 & 870323,870332 \\
\hline Ex17 & 66958354262 & 12442239412 & 18.58 & 870323,870332 \\
\hline Im17 & 76927696001 & 16361377173 & 21.27 & 870323,870332 \\
\hline Ex18 & 74304337029 & 13016796151 & 17.52 & 870323,870332 \\
\hline Im18 & 82323499049 & 16998109723 & 20.65 & 870323,870322 \\
\hline Ex19 & 74903753410 & 12012388233 & 16.04 & 870323,870332 \\
\hline Im19 & 82346289356 & 16689005679 & 20.27 & 870323,870322 \\
\hline
\end{tabular}

Source: original calculations based on the UN Comtrade Database (2020).

Table 9. The Grubel-Lloyd (GL), horizontal and vertical intra-industry trade (HIIT, VIIT) indexes of the automotive industry in the EU-28-Japan trade, 2010-2019

\begin{tabular}{|c|c|c|c|}
\hline Years & GL & VIIT & HIIT \\
\hline 2010 & 0.62891 & 0.53106 & 0.95197 \\
\hline 2011 & 0.71186 & 0.64668 & 0.93196 \\
\hline 2012 & 0.62026 & 0.61966 & 0.98679 \\
\hline 2013 & 0.67489 & 0.65518 & 0.95053 \\
\hline 2014 & 0.68049 & 0.66163 & 0.96677 \\
\hline 2015 & 0.6561 & 0.59741 & 0.97133 \\
\hline 2016 & 0.57288 & 0.57257 & 0.97742 \\
\hline 2017 & 0.57258 & 0.57182 & 0.96399 \\
\hline 2018 & 0.50097 & 0.50077 & 0.96479 \\
\hline 2019 & 0.4565 & 0.45602 & 0.96835 \\
\hline
\end{tabular}

Source: original calculations based on the UN Comtrade Database (2020).

High-quality VIIT, characterised by a relative unit value of export-to-import ratio higher than 1.15 (marked with italics in Table 10), dominated each year for 22 of the 58 studied codes and was recorded 415 times in total (71.55\% of total cases). Low-quality VIIT was recorded 108 times. It is worth mentioning that in 2019 high-quality VIIT was the dominant pattern of trade for 47 of the 58 studied codes, the highest proportion of high-quality VIIT codes recorded. The second-highest result was recorded in 2016 (43 codes), while the number of codes ranged mostly between 39-40 in the remaining years. 
Table 10. The dominant patterns of intra-industry trade in the automotive industry in the EU-28-Japan trade in the years 2010-2019

\begin{tabular}{|c|c|c|c|c|c|c|c|c|c|c|c|c|c|c|c|c|c|c|c|c|c|}
\hline Six-digit HS code & 2010 & 2011 & 2012 & 2013 & 2014 & 2015 & 2016 & 2017 & 2018 & 2019 & Six-digit HS code & 2010 & 2011 & 2012 & 2013 & 2014 & 2015 & 2016 & 2017 & 2018 & 2019 \\
\hline 401110 & VIIT & VIIT & VIIT & HIIT & VIIT & VIIT & HIIT & HIIT & HIIT & VIIT & 852729 & VIIT & VIIT & VIIT & VIIT & VIIT & VIIT & VIIT & VIIT & VIIT & VIIT \\
\hline 401120 & VIIT & VIIT & VIIT & VIIT & VIIT & VIIT & VIIT & VIIT & VIIT & VIIT & 853921 & VIIT & VIIT & VIIT & VIIT & VIIT & VIIT & VIIT & VIIT & VIIT & VIIT \\
\hline 401220 & VIIT & VIIT & VIIT & VIIT & VIIT & VIIT & HIIT & VIIT & VIIT & VIIT & 853929 & VIIT & VIIT & VIIT & VIIT & VIIT & VIIT & VIIT & VIIT & VIIT & VIIT \\
\hline 401290 & VIIT & VIIT & HIIT & VIIT & HIIT & VIIT & VIIT & VIIT & VIIT & VIIT & 854430 & VIIT & VIIT & VIIT & VIIT & HIIT & HIIT & HIIT & HIIT & VIIT & VIIT \\
\hline 401310 & VIIT & VIIT & VIIT & VIIT & HIIT & VIIT & VIIT & VIIT & VIIT & VIIT & 870600 & VIIT & VIIT & VIIT & VIIT & VIIT & VIIT & VIIT & VIIT & VIIT & VIIT \\
\hline 700711 & VIIT & VIIT & VIIT & VIIT & VIIT & VIIT & VIIT & VIIT & VIIT & VIIT & 870710 & VIIT & VIIT & VIIT & VIIT & VIIT & VIIT & VIIT & VIIT & VIIT & VIIT \\
\hline 700721 & VIIT & VIIT & VIIT & HIIT & VIIT & VIIT & VIIT & VIIT & HIIT & VIIT & 870810 & VIIT & VIIT & VIIT & VIIT & HIIT & VIIT & VIIT & VIIT & VIIT & VIIT \\
\hline 700910 & HIIT & HIIT & VIIT & VIIT & VIIT & VIIT & VIIT & HIIT & VIIT & VIIT & 870821 & VIIT & VIIT & VIIT & VIIT & VIIT & VIIT & VIIT & VIIT & VIIT & VIIT \\
\hline 830120 & VIIT & HIIT & VIIT & HIIT & VIIT & VIIT & VIIT & VIIT & VIIT & VIIT & 870829 & VIIT & VIIT & VIIT & VIIT & VIIT & VIIT & VIIT & VIIT & VIIT & VIIT \\
\hline 830230 & VIIT & VIIT & VIIT & VIIT & VIIT & VIIT & VIIT & VIIT & VIIT & VIIT & 870840 & VIIT & VIIT & VIIT & VIIT & VIIT & VIIT & VIIT & VIIT & VIIT & VIIT \\
\hline 840731 & VIIT & VIIT & VIIT & VIIT & VIIT & VIIT & VIIT & VIIT & VIIT & VIIT & 870850 & HIIT & HIIT & HIIT & VIIT & VIIT & VIIT & VIIT & VIIT & VIIT & VIIT \\
\hline 840732 & HIIT & VIIT & VIIT & VIIT & VIIT & VIIT & VIIT & VIIT & VIIT & VIIT & 870870 & HIIT & VIIT & VIIT & VIIT & VIIT & VIIT & VIIT & VIIT & VIIT & VIIT \\
\hline 840733 & VIIT & VIIT & VIIT & VIIT & VIIT & VIIT & VIIT & VIIT & VIIT & VIIT & 870880 & VIIT & VIIT & VIIT & VIIT & VIIT & VIIT & VIIT & VIIT & VIIT & VIIT \\
\hline 840734 & VIIT & VIIT & VIIT & VIIT & VIIT & VIIT & VIIT & VIIT & VIIT & VIIT & & HIIT & VIIT & HIIT & HIIT & HIIT & HIIT & VIIT & VIIT & HIIT & HIIT \\
\hline 840790 & VIIT & VIIT & VIIT & VIIT & VIIT & VIIT & VIIT & VIIT & VIIT & VIIT & 870892 & VIIT & VIIT & VIIT & VIIT & VIIT & VIIT & VIIT & VIIT & VIIT & VIIT \\
\hline 840820 & VIIT & VIIT & VIIT & VIIT & VIIT & VIIT & VIIT & VIIT & VIIT & VIIT & 870893 & HIIT & HIIT & VIIT & VIIT & VIIT & VIIT & VIIT & VIIT & VIIT & VIIT \\
\hline 840991 & VIIT & VIIT & VIIT & VIIT & VIIT & VIIT & VIIT & VIIT & VIIT & VIIT & 870894 & VIIT & VIIT & VIIT & VIIT & VIIT & VIIT & VIIT & VIIT & VIIT & VIIT \\
\hline 840999 & VIIT & VIIT & VIIT & VIIT & HIIT & HIIT & VIIT & HIIT & VIIT & HIIT & 870899 & VIIT & VIIT & HIIT & VIIT & VIIT & VIIT & VIIT & VIIT & VIIT & VIIT \\
\hline 841330 & VIIT & VIIT & VIIT & VIIT & VIIT & VIIT & VIIT & VIIT & VIIT & VIIT & 910400 & VIIT & VIIT & VIIT & VIIT & VIIT & VIIT & VIIT & VIIT & VIIT & VIIT \\
\hline 842542 & VIIT & HIIT & VIIT & VIIT & VIIT & VIIT & VIIT & VIIT & VIIT & VIIT & 940120 & HIIT & VIIT & VIIT & VIIT & VIIT & VIIT & VIIT & VIIT & VIIT & VIIT \\
\hline 848390 & VIIT & VIIT & VIIT & HIIT & HIIT & VIIT & VIIT & VIIT & VIIT & VIIT & 940190 & VIIT & VIIT & VIIT & VIIT & VIIT & VIIT & VIIT & VIIT & VIIT & VIIT \\
\hline 850710 & VIIT & VIIT & VIIT & VIIT & VIIT & VIIT & VIIT & VIIT & VIIT & VIIT & 870321 & VIIT & VIIT & VIIT & VIIT & VIIT & VIIT & VIIT & VIIT & VIIT & VIIT \\
\hline 850730 & VIIT & VIIT & VIIT & VIIT & VIIT & VIIT & VIIT & VIIT & VIIT & VIIT & 870322 & VIIT & VIIT & VIIT & VIIT & VIIT & VIIT & VIIT & VIIT & VIIT & VIIT \\
\hline 850740 & VIIT & VIIT & VIIT & HIIT & VIIT & VIIT & VIIT & VIIT & VIIT & VIIT & 870323 & VIIT & VIIT & VIIT & VIIT & VIIT & VIIT & VIIT & VIIT & VIIT & VIIT \\
\hline 850780 & VIIT & VIIT & VIIT & VIIT & VIIT & VIIT & VIIT & VIIT & VIIT & VIIT & 870324 & VIIT & VIIT & VIIT & VIIT & VIIT & VIIT & VIIT & VIIT & VIIT & VIIT \\
\hline 851230 & VIIT & VIIT & VIIT & VIIT & HIIT & HIIT & HIIT & VIIT & VIIT & VIIT & 870331 & VIIT & VIIT & VIIT & HIIT & HIIT & HIIT & VIIT & VIIT & VIIT & VIIT \\
\hline 851290 & VIIT & VIIT & VIIT & VIIT & VIIT & VIIT & VIIT & VIIT & VIIT & VIIT & 870332 & HIIT & HIIT & VIIT & VIIT & VIIT & VIIT & VIIT & VIIT & VIIT & VIIT \\
\hline 851829 & VIIT & VIIT & VIIT & VIIT & VIIT & VIIT & VIIT & VIIT & VIIT & VIIT & 870333 & VIIT & VIIT & VIIT & VIIT & VIIT & VIIT & VIIT & VIIT & VIIT & VIIT \\
\hline 852721 & VIIT & VIIT & HIIT & VIIT & VIIT & VIIT & VIIT & HIIT & VIIT & VIIT & 870390 & HIIT & HIIT & VIIT & VIIT & VIIT & HIIT & VIIT & VIIT & VIIT & VIIT \\
\hline
\end{tabular}

Source: original compilation based on the UN Comtrade Database (2020). 
However, as stressed by Gabrisch and Segnana (2003), interpreting VIIT only through the prism of quality differences, as in the models of Falvey (1981), Falvey and Kierzkowski (1985) and Shaked and Sutton (1984), could be misleading in some cases. Gabrisch and Segnana (2003) argued that a relative unit value higher than 1.15 may result in either a quality advantage or cost disadvantage for the exports of a given country. Such cost disadvantages reflect itrade deficit of the industry, which is accompanied by a higher unit value of export in comparison to the corresponding imports; this may be the case for the EU-Japan automotive trade (Table 8). However, such cost disadvantages tend to shrink over time as value chains are fragmented and relocated, for instance, from Western to Central Eastern European countries. The downward trend in the EU trade deficit with Japan in the automotive industry, which reflects higher export dynamics as compared to imports in recent years, may lead to a hypothetical situation in which the industry records a trade surplus due to the higher export than import prices resulting from a quality advantage.

\section{Regulatory implications of the EU-Japan EPA for the automotive industry}

As a consequence of the implementation of the EPA, all exports of vehicles, their parts and equipment from the EU to Japan and from Japan to the EU are duty-free, except for leather parts of seats used in vehicles (940190). The tariff duty for the EU's leather parts amounts to $3.8 \%$, and the duty for Japanese products is 3.1\%. Both duties, however, will be gradually eliminated by 1 April 2028 (EU-Japan Centre for Industrial Cooperation 2020; Japan Customs, 2020).

Annexes 2-C, 3-B and Appendix 3-B-1 of the EU-Japan EPA provide a set of regulations dedicated to the automotive industry. Annex $2-C$ addresses trade in motor vehicles and their parts and equipment regulated by the 1958 Agreement concerning the Adoption of Harmonised Technical United Nations Regulations for Wheeled Vehicles, Equipment and Parts or the 1998 Agreement concerning the Establishing of Global Technical Regulations for Wheeled Vehicles, Equipment and Parts. According to Article 3 of Annex 2-C, the main objectives of this Annex are (1) the promotion of safe, environmentally friendly, energy-efficient motor vehicles, parts and equipment; (2) the facilitation of trade and improvement of market access between the EU and Japan; (3) the harmonisation of standards and requirements according to the World Forum for Harmonisation of Vehicle Regulations, including the mutual recognition of type approvals granted under UN Regulations; and (4) the achievement of regulatory convergence by implementing the UN Regulations and Global Technical Regulation in line with the 1998 Agreement (MOFA, 2019). Under the EPA's special provisions concerning vehicles and their parts under Annex 2-C, the EU and Japan declared mutual recognition of type approval certificates without additional testing, certification or documentation. Following the same international standards will significantly reduce the time and costs required for each country to enter the other's automotive market. Importantly, a limited number of hydrogen-fuelled vehicles manufactured in the EU can access the Japanese market without the necessity of any modifications. However, some currently binding material restrictions are discussed in phase 2 of GTR13, adopted in June 2013, which addresses hydrogen and fuel cell vehicles.

An accelerated settlement procedure applies to any dispute over domestic regulatory procedures. This stipulates that the consultation period cannot exceed 15 days, the preparation of an interim report by the appointed panel cannot exceed 60 days from the day of its establishment, the final report must be ready no later than 15 days after the interim report is issued and complaints should be addressed within a reasonable period up to 90 days after the publication of the final report. Also, if there is no satisfactory response or compensation upon request, the complaining party can suspend any obligations, including reducing or eliminating customs duties for the products under dispute.

Annex 3-B and Appendix 3-B-1 concern rules of origin for trade in vehicles and their parts and equipment. The EPA relies on a self-certification system, which means that the supplier's declaration of origin may be delivered by a supplier in Japan to a producer in Japan to determine the originating status of the product of four-digit HS codes $8407,8408,8701$ and 8708 . There is also a clause of bilateral cumulation, which allows for treating materials originating in Japan as originating in the EU and vice versa if those products serve as materials in production processes in the other country. 
For selected four-digit HS codes in the automotive industry, the thresholds of product-specific rules of origin are determined for Ex-Works (EXW) and Free on Board (FOB) commercial terms, to be used interchangeably (Table 11). In most cases, MaxNOM/RVC thresholds are decreased/increased by $10 \%$ after three or five years from the day of the EPA's entry into force. The sole exception is HS code 8703; for this code, MaxNOM/RVC thresholds are decreased/increased by $5 \%$ twice, three and six years after the day of the EPA's entry into force.

Table 11. Thresholds of product-specific rules of origin for vehicles and their parts according to Appendix 3-B-1

\begin{tabular}{|c|c|c|c|c|c|}
\hline Four-digit HS code & MaxNOM $^{a}(E X W)$ & $\mathrm{RVC}^{\mathrm{b}}$ (FOB) & Four-digit HS code & MaxNOM (EXW) & RVC (FOB) \\
\hline 8407 & $\begin{array}{c}60 \%(1-3)^{c} \\
50 \%(4-)\end{array}$ & $\begin{array}{c}45 \%(1-3) \\
55 \%(4-)\end{array}$ & 8408 & $\begin{array}{c}60 \%(1-3) \\
50 \%(4-)\end{array}$ & $\begin{array}{c}45 \%(1-3) \\
55 \%(4-)\end{array}$ \\
\hline 8703 & $\begin{array}{c}55 \%(1-3) \\
50 \%(4-6) \\
45 \%(7-) \\
\end{array}$ & $\begin{array}{c}50 \%(1-3) \\
55 \%(4-6) \\
60 \%(7-) \\
\end{array}$ & 8706 & $\begin{array}{c}55 \%(1-5) \\
45 \%(6-)\end{array}$ & $\begin{array}{c}50 \%(1-5) \\
60 \%(6-)\end{array}$ \\
\hline 8707 & $\begin{array}{c}55 \%(1-5) \\
45 \%(6-)\end{array}$ & $\begin{array}{c}50 \%(1-5) \\
60 \%(6-)\end{array}$ & $8708^{d}$ & $\begin{array}{c}60 \%(1-3) \\
50 \%(4-)\end{array}$ & $\begin{array}{c}45 \%(1-3) \\
55 \%(4-)\end{array}$ \\
\hline
\end{tabular}

a The maximum value of non-originating materials.

b The regional value content.

'Numbers in the brackets indicate years after the day of the EPA's entry into force according to the following formula: beginning of year - end of year.

d For this four-digit HS code, the rule of change of tariff heading (CTH) applies.

Source: original compilation based on the European Commis $\neg$ sion's Directorate-General for Trade (2018a).

There is also an innovative solution of claiming preferential tariff treatment by importers relying on the "importer's knowledge." The product-specific rules of origin applicable to six-digit HS codes 870321 and 870390 are determined by referring to the production processes of selected automotive parts. These parts comprise materials classified under six-digit HS codes 700711, 700721, 870710, 870810, 870829 and 870850 , originating in the place where those processes are performed, i.e. in the EU or Japan. There is also a possibility of considering materials of four-digit HS codes 8407,8544 and 8708 originating in the third country as originating materials if there is a free trade agreement (FTA) signed between a given third country and the EU or Japan or any arrangement on the administrative cooperation in this field.

\section{The automotive industry and Brexit}

The withdrawal of the United Kingdom from the European Union as a result of the referendum on 23 June 2016, colloquially termed 'Brexit,' is a source of serious concern for the automotive industry both in the EU and Japan. Approximately one-third of the EU's automotive exports were directed to the UK every year, while over half of the UK's exports were destined for the EU. As argued by Dorussen (2019), since the mid-1980s, Japan had perceived the UK as a gateway to the markets of continental Europe and the second-most important location for FDI after the United States. Over 1.000 Japanese enterprises established affiliates in the UK, and more than $15 \%$ of all entities from that country operate in the EU member states, with the employment of over 140 thousand workers. Around half of all motor vehicles manufactured in the UK are Japanese, and most of these are sold to the EU countries. The UK's favourable business environment and investment climate, as well as the highly competitive financial services market of London attracted Japanese automotive enterprises for decades. However, these advantages have eroded since Brexit. For instance, Nissan cancelled further investment in its manufacturing facilities in that country, while electronic enterprises Sony and Panasonic decided to relocate their headquarters to the Netherlands.

Reestablishing customs borders between the UK and the EU creates the risk of charging duties twice, first on automotive parts imported from the EU and again on final products exported to the EU after assembly within integrated value chains. Another challenge is a change in customs clearance procedures, including the removal of the mutual recognition of authorised economic operators (AEO) and the diversification of the rules of origin after Brexit. These factors would impact the costs of logistics operations and the international competitiveness of automotive businesses. 
Until the end of 2020, the EU and the UK were engaged in a transition period to determine their future rules of trade. With no EU-UK FTA until 31 December, bilateral trade in 2021 would be conducted under non-preferential WTO rules, which implied the imposition of tariffs of $10 \%$ on cars and up to $22 \%$ on vans and trucks. In such a case, according to estimations by ACEA (2020b), combined the EU- and the UK-based automotive production would be reduced by more than 3 million units by 2025, translating to losses of EUR 57.7 billion and 52.8 billion on the EU and UK side, respectively.

Ultimately, on 31 December 2020, the content of the Trade and Cooperation Agreement (TCA) between the EU and the UK was published, although its application from January 1, 2021 is, in light of the declarations of the representatives of the European Commission, temporary. The Free Trade Agreement provides for duty-free trade and no quota for all product ranges that meet the rules of origin.

Technical aspects of trade in motor vehicles, their parts and equipment are described in Annex TBT-1 of the above-mentioned TCA. In particular, reference was made to the obligations arising from the 1958 and 1998 multilateral agreements, alike in the case of Annexes 2-C, 3-B and Annex 3-B-1 of the EU-Japan EPA. At the same time, actions aimed at regulatory convergence in the area of applying international standards for production and trade in the automotive industry assortment were declared. Certification based on the UN Universal International Whole Vehicle Type Approval (U-IWVTA) was used as a benchmark, including vehicle parts and equipment. Moreover, the Annex TBT-1 stipulates that neither party has the authority to restrict market access to an assortment with hitherto unknown properties and technical parameters for which there are no indications of a threat to public health, safety and the natural environment (European Union, 2020).

It is worth noting, however, that representatives of ACEA, in their official position, pointed out that the conclusion of the agreement did not eliminate the uncertainty and risk related to the implementation of new administrative procedures in connection with the restoration of the customs border between the EU and the UK. The fact that the content of the agreement consisting of more than 1.5 thousand pages was in fact published a few hours before its entry into force was, on the one hand, welcomed with relief and, on the other hand, with great caution.

The EU-UK FTA addresses numerous concerns over Brexit from the perspective of both European and Japanese automotive enterprises. The key aspects of future EU-UK trade relations include (in addition to the aforementioned tariffs) the simplification of customs procedures and the principle of cumulation of origin. The last aspect is significant when considering the specificity of the automotive industry and the resulting division of labour between the EU and the UK in manufacturing automotive parts and equipment.

From Japan's perspective, it is also crucial to maintain the status of the EU citizens in the British labour market employed in the automotive industry and to keep this labour market as open and liberal as possible under the new legal conditions. Considering the role of London as the European financial services centre, there is an expectation that financial regulations in the UK and the EU will converge in the mid- and long-term. It is also expected that the single passporting system will be maintained to avoid the duplication of registry procedures for Japanese financial institutions or their relocation to continental Europe.

Given that Japanese automotive enterprises operate across the EU and the UK, including MNEs and small and medium-sized suppliers and subcontractors, they expect to benefit from the free flows of services between the UK and the EU. These flows include those provided by shared services centres as well as from the movement of capital, e.g. tax exemption, for dividends transferred among associated enterprises. Preserving the recognition and mutually binding status of all licenses issued in favour of Japanese enterprises in the UK and the EU is another priority. Finally, it is important to maintain a homogenous regime of the protection of intellectual property rights and information in the UK and the $\mathrm{EU}$, including the free transfer of data as well as a uniform system of standards and certification addressing motor vehicles to avoid the escalation of R\&D and administrative costs of businesses.

Another option would be the accession of the UK to the Comprehensive and Progressive Agreement on Trans-Pacific Partnership (CPTPP). The CPTPP is a mega-regional trade agreement signed by eleven countries of the Asia-Pacific region, including Japan, Australia, Brunei Darussalam, Canada, Chile, Malaysia, Mexico, New Zealand, Peru, Singapore and Viet Nam on 8 March 2018 in Santiago (Chile). In early 2018, the British Department of International Trade officially considered CPTPP membership as an opportunity to enter new export markets after Brexit, which was welcomed favourably by Japan's former 
Prime Minister Shinzō Abe. On 11 September 2020, after three months of talks, the UK-Japan Comprehensive Economic Partnership Agreement (CEPA) was officially accepted by International Trade Secretary Liz Truss and Japan's Foreign Minister Motegi Toshimitsu (Department for International Trade, 2020). According to declarations, CEPA goes beyond the EU-Japan EPA on a limited range of issues, including cutting-edge digital and data provisions to be established in line with the CPTPP approach. Some of Japan's automotive parts are expected to benefit from the streamlined regulatory procedures and faster tariff reduction than under the EU-Japan EPA when entering the UK market to provide support for Japanese investors residing in Britain. EU-originated automotive parts exported from the UK to Japan will be considered as the UK-originated under CEPA under the principle of cumulation of origin; however, with no EU-UK trade deal in place, the treatment of the UK-originated goods consisting of Japan's parts in the EU would be fairly uncertain. Importantly, the UK-Japan CEPA involves a commitment to launch CPTPP accession talks by the British government, starting with bilateral negotiations with Australia, Canada and New Zealand. From Japan's economic perspective, however, the attractiveness of the UK came down to free and open access to the EU market. Thus, Japanese enterprises may not necessarily benefit and appreciate possible future British membership in the CPTPP.

Considering the concerns that some analysts have expressed about the EU automotive market concerning the imposition of strong competitive pressure from Japanese manufacturers, Garnsey (2019) stressed that, contrary to predictions, the entry into force of the EU-Republic of Korea FTA did not boost imports of motor vehicles to the EU. Instead, the agreement tripled exports of the EU-originated cars to the Republic of Korea in the years 2011-2015 to more than USD 6 billion. Thus, the automotive industry contributed considerably to the increase in the total trade volume between the EU and the Republic of Korea, which grew by $55 \%$ in the five-year study period.

\section{CONCLUSIONS}

An analysis of intra-industry trade between the EU and Japan, with reference to the implications of the establishment of the EPA, was challenged by theoretical and empirical objections, as well as regulatory uncertainty. Firstly, the results of studies on intra-industry trade depend on the degree of disaggregation of statistics and the choice of trade nomenclature. We conducted research relying on six-digit HS codes to address product differentiation as the assumption of intra-industry trade theory. Secondly, the automotive industry faces significant challenges due to Brexit and its consequences, including the regulatory frameworks of the future EU-UK and UK-Japan trade relations.

The dominance of intra-industry trade in total trade between the EU and Japan was indicated in line with studies by Benz and Yalcin (2015). Statistical analysis made by the authors confirmed the potential of intra-industry trade in the automotive industry, reflected by its increasing volume as well as the role of high-quality VIIT. HIIT played an increasingly marginal role in total IIT in the study period, which indicates the rising importance of the diversity of factor endowments across the countries involved in the manufacturing of motor vehicles and their parts and equipment. As long as differences in income, technological development, resource base and consumer preferences impact IIT in the automotive industry between the EU and Japan, the vertical differentiation of products will be dominant. Therefore, the fragmentation of value chains and relocation of automotive parts manufacturing and assembly to CEE on the one side, and Southeast Asian countries on the other, along with the concept of the product-quality cycle, serve as a trigger of VIIT. This is in line with studies by Aturupane, Djankov and Hoeckman (1999), who pointed out the relevance of industry-specific determinants such as FDI for VIIT.

From the perspective of the EU, it is important to stress an improvement of the trade balance in the automotive industry with Japan and the rising position of Japan as a trade partner of the EU. Trade liberalisation under the EU-Japan EPA, concerning both tariff and non-tariff measures, may contribute to the further expansion of the EU-Japan bilateral trade in the automotive industry. However, mid- and long-term trends in intra-industry flows, including their horizontal and vertical patterns, depend on the competitiveness of the industry, resulting from quality and cost differences. Regulatory conver- 
gence and standards harmonisation are important aspects of EPA that reduce time and costs for businesses, including the promotion of safe, energy-efficient and environmentally friendly automotive manufacturing, mutual recognition of approval certificates and the principle of cumulation of origin.

Given the limitations of this study, further research should disaggregate analysis at the product level to the country-country axis to eliminate distortions of data on the IIT patterns and verify the relevance of country- and industry-specific determinants of trade, including FDI. Furthermore, detailed studies of implications of the EU-Japan EPA should be undertaken in one year, when regulatory frameworks of the EU-UK and UK-Japan trade relations will be finally agreed upon and formalised.

\section{REFERENCES}

Abd-el-Rahman, K. (1984). Firms' Competitive and National Comparative Advantage as Joint Determinants of Trade Composition. Weltwirtschafliches Archiv, 127(1), 83-97. https://doi.org/10.1007/BF0270731

ACEA (2016). Economic and Market Report EU Automotive Industry Quarter 4 2015. Brussels: European Automobile Manufacturers' Association. Retrieved from

https://www.acea.be/uploads/statistic_documents/Economic_and_Market_Report_Q4_2015.pdf on August 16, 2020.

ACEA (2017). Economic and Market Report EU Automotive Industry Quarter 4 2015, Brussels: European Automobile Manufacturers' Association. Retrieved from

https://www.acea.be/uploads/statistic_documents/Economic_and_Market_Report_Q4_2016.pdf on August 16, 2020.

ACEA (2018). Economic and Market Report EU Automotive Industry Quarter 4 2015, Brussels: European Automobile Manufacturers' Association. Retrieved from https://www.acea.be/uploads/statistic_documents/Economic_and_Market_Report_Q4_2017.pdf on August 23, 2020.

ACEA (2019). Economic and Market Report EU Automotive Industry Full-year 2018, Brussels: European Automobile Manufacturers' Association. Retrieved from

https://www.acea.be/uploads/statistic_documents/Economic_and_Market_Report_full-year_2018.pdf on August 20, 2020.

ACEA (2020). Economic and Market Report EU Automotive Industry Full-year 2019, Brussels: European Automobile Manufacturers' Association. Retrieved from

https://www.acea.be/uploads/statistic_documents/Economic_and_Market_Report_full-year_2019.pdf on August 20, 2020.

ACEA (2020a). Interactive map: Automobile assembly and production plants in Europe. Retrieved from

https://www.acea.be/statistics/article/automobile-assembly-engine-production-plants-in-europe on $\mathrm{Au}$ gust 22, 2020.

ACEA (2020b). Only weeks left to save EU and UK auto sectors from $€ 110$ billion 'no deal' Brexit disaster. Retrieved from https://www.acea.be/press-releases/article/only-weeks-left-to-save-eu-and-uk-auto-sectorsfrom-110-billion-no-deal-bre on August 24, 2020.

Ambroziak, Ł. (2017). Potencjalny wpływ umowy o partnerstwie gospodarczym UE-Japonia na polski handel rolno-spożywczy z Japonią [The potential impact of EU-Japan EPA on Polish agri-food trade with Japan]. Gospodarka Regionalna i Międzynarodowa, 53(2), 117-129. https://doi.org10.18276/sip.2018.53/2-09

Anderer, Ch., Dür, A., \& Lechner, L. (2020). Trade Policy in a "GVC World": Multinational Corporations and Trade Liberalization. Business and Politics, March, 1-28. https://doi.org/10.1017/bap.2020.4

Aturupane, Ch., Djankov, S., \& Hoeckman, B. (1999). Horizontal and Vertical Intra-Industry trade between Eastern Europe and the European Union. Weltwirtschfliches Archiv, 135(1), 62-81. https://doi.org/10.1007/BF02708159

Baccini, L., Dür, A., \& Elsig, M. (2018). Intra-Industry Trade, Global Value Chains, and Preferential Tariff Liberalization. International Studies Quarterly, 62(2), 329-340. https://doi.org/10.1093/isq/sqy006

Baccini, L., \& Dür, A. (2018). Global Value Chains and Product Differentiation: Changing the Politics of Trade. Global Policy, 9(2), 49-97. https://doi.org/10.1111/1758-5899.12614

Bagchi, S., \& Bhattacharyya, S. (2019). Country-Specific Determinants of Intra-Industry Trade in India. Foreign Trade Review, 54(3), 129-158. https://doi.org/10.1177/0015732519851630 
Balassa, B. (1966). Tariff Reductions and Trade in Manufactures among Industrial Countries. American Economic Review, 56(3), 466-473. Retrieved from https://www.jstor.org/stable/1823779?seq=1 on August 26, 2020.

Balassa, B. (1986). The Determinants of Intra-Industry Specialization in United States Trade. Oxford Economic Papers, 38(2), 220-233. https://doi.org/10.1093/oxfordjournals.oep.a041737

Bekker, H. (2020). Retrieved from https://www.best-selling-cars.com/japan/2020-q1-japan-best-selling-carbrands-models-and-minicars/ on August 26, 2020.

Benz, S., \& Yalcin, E. (2015). Productivity versus Employment: Quantifying the Economic Effects of an EU-Japan Free Trade Agreement. The World Economy, 38(6), 935-961. https://doi.org/10.1111/twec.12205

Bergstrand, J.H. (1990). The Heckscher-Ohlin-Samuelson Model, the Linder Hypothesis and the Determinants of Bilateral Intra-Industry Trade. The Economic Journal, 100(403), 1216-1229. https://doi.org/10.2307/2233969

Bobowski, S. (2017). Another mega-regional trade bloc under construction? The case of the European Union (EU) - Japan Free Trade Agreement (FTA). Asia-Pacific Journal of EU Studies, 15(2), 25-40.

Bobowski, S. (2018). Measurement of intra-industry trade in international production networks in the HDD industry. The case of East Asia. Transformations in Business \& Economics, 17(2A(44A)), 390-409. Retrieved from https://www.researchgate.net/publication/328382601_Measurement_of_intra-industry_trade_in_international_production_networks_in_the_HDD_industry_The_case_of_East_Asia on August 26, 2020.

Brander, J.A. (1981). Intra-Industry Trade in Identical Commodities. Journal of International Economics, 11(1), 114. https://doi.org/10.1016/0022-1996(81)90041-6

Danks, E. (2018). The EU-Japan EPA and SPA and 'Abe Doctrine': Reinforcing Norms Globally, Changing them Domestically. European Institute for Asian Studies, July.

de Prado, C. (2017). Towards a Substantial EU-Japan Partnership. European Foreign Affairs Review, 22(4), 435454. Retrieved from https://cadmus.eui.eu/bitstream/handle/1814/51204/CdP\%202017\%20EUJP\%20EFAR\%2022_0401.pdf?sequence=3 on August 26, 2020.

Department for International Trade (2020). UK and Japan agree historic free trade agreement. Retrieved from https://www.gov.uk/government/news/uk-and-japan-agree-historic-free-trade-agreement on September 11, 2020.

Dixit, A.K., \& Norman, V. (1980). Theory of International Trade: A Dual, General Equilibrium Approach. New York: Cambridge University Press.

Dixit, A.K., \& Stiglitz, J. (1977). Monopolistic Competition and Optimum Product Diversity. American Economic Review, 67(3), 217-238. https://doi.org/10.7916/D8S75S91

Dorussen, H. (2019). Retrieved from https://blogs.Ise.ac.uk/europpblog/2019/02/16/why-the-EU-Japan-tradedeal-matters-for-brexit/ on August 27, 2020.

European Union (2020). Trade and Cooperation Agreement between the European Union and the United Kingdom. Retrieved from https://eur-lex.europa.eu/legal-content/EN/TXT/PDF/?uri=CELEX:22020A1231(01)\&from=EN on February 22, 2021.

EU-Japan Centre for Industrial Cooperation (2020). EU-Japan EPA Factsheet. Vehicles and parts, EU-Japan Centre. Retrieved from https://www.eubusinessinjapan.eu/sites/default/files/vehicles_factsheet.pdf on September 14, 2020.

European Commission's Directorate-General for Trade (2018). The Economic Impact Of The EU - Japan Economic Partnership Agreement (EPA), Luxembourg: European Commission. Retrieved from http://trade.ec.europa.eu/doclib/docs/2018/july/tradoc_157116.pdf on September 15, 2020.

European Commission's Directorate-General for Trade (2018a). Annex 2-B. Retrieved from https://trade.ec.europa.eu/doclib/docs/2018/august/tradoc_157231.pdf on October 23, 2020.

Falvey, R.E. (1981). Commercial Policy and Intra-Industry Trade. Journal of International Economics, 11(4), 495511. https://doi.org/10.1016/0022-1996(81)90031-3

Falvey, R.E., \& Kierzkowski, H. (1987). Product Quality, Intra-Industry Trade and (Im)perfect Competition. In H. Kierzkowski (Ed.), Protection and Competition in International Trade: Essays in Honor of W.M. (pp. 143-161). Corden, Oxford: Blackwell.

Felbermayr, G., Kimura, F., Okubo, T., \& Steininger, M. (2018). Quantifying the EU-Japan Economic Partnership Agreement, Munich: CESifo Working Papers. https://doi.org/10.1016/j.jjie.2018.12.007 
Felbermayr, G., Kimura, F., Okubo, T., Steininger, M., \& Yalcin, E. (2017). On the economics of an EU-Japan Free Trade Agreement, Munich: ifo Center for International Economics. Retrieved from

https://www.ifo.de/DocDL/ifo_Forschungsberichte_86_2017_Felbermayr_etal_EU-JapanFreeTrade.pdf on September 4, 2020.

Fontagné L., \& Freudenberg, M. (1997). Intra-industry trade: Methodological issues reconsidered, CEPII Working Paper 1.

Francois, J., Manchin, M., \& Norberg, H. (2011). Economic Impact Assessment of an FTA between the EU and Japan. Retrieved from https://trade.ec.europa.eu/doclib/docs/2017/july/tradoc_155782.pdf on August 26, 2020.

Gabrisch, H., \& Segnana, M.L. (2003). Vertical and horizontal patterns of intra-industry trade between EU and candidate countries. Halle: Institut Für Wirtschaftsforschung Halle - IWH.

Garnsey, S. (2019). Auto sector wins out in EU-Japan trade deal. Retrieved from https://www.automotivelogistics.media/auto-sector-wins-out-in-EU-Japan-trade-deal/37514.article on Au-gust 25, 2020.

Gilson, J. (2019). EU-Japan Relations and the Crisis of Multilateralism. London: Routledge.

Greenaway, D. (1983). Inter-Industry Trade and Intra-Industry Trade in Switzerland, 1965-1977. Weltwirtschaftliches Archiv, 119, 109-121. https://doi.org/10.1007/BF02708173

Greenaway, D. (1984). The Measurement of Product Differentiation in Empirical Studies of Trade Flows. In H. Kierzkowski (Ed.), Monopolistic Competition and International Trade (pp. 230-249). Oxford.

Greenaway, D., \& Milner, C. (1981). Trade Imbalance Effects in the Measurement of Intra-Industry Trade. Weltwirtschaftliches Archiv, 117, 756-762. https://doi.org/10.1007/BF02708125

Greenaway, D., \& Milner, C. (1983). On the Measurement of Intra-Industry Trade. The Economic Journal, 93(372), 900-908. https://doi.org/10.2307/2232755

Greenaway, D., Hine, R., \& Milner, C. (1994). Country-Specific Factors and the Pattern of Horizontal and Vertical Intra-Industry Trade in the UK. Weltwirtschaftliches Archiv, 130(1), 77-100. https://doi.org/10.1007/BF02706010

Grubel, H.G., \& Lloyd, P.J. (1971). The Empirical Measurement of Intra-Industry Trade. Economic Record, 47(4), 494-517. https://doi.org/10.1111/j.1475-4932.1971.tb00772.x

Grubel, H.G., \& Lloyd, P.J. (1975). Intra-Industry Trade: The Theory and Measurement of International Trade in Differentiated Products. New York: Wiley.

Grübler, J., Reiter, O., \& Stehrer, R. (2019). The EU-Japan EPA: A Case for Non-tariff Measures. CESifo Forum, 20(2), 17-25. Retrieved from https://ideas.repec.org/p/wii/wpaper/182.html on August 28, 2020.

Hellvin, L. (1996). Vertical Intra-Industry Trade Between China and OECD Countries. Development Centre Technical Papers, 114, 1-37. https://doi.org/10.1787/18151949

Helpman, E. (1981). International Trade in the Presence of Product Differentiation, Economies of Scale and Monopolistic Competition. Journal of International Economics, 11(3), 305-340. https://doi.org/10.1016/00221996(81)90001-5

Helpman, E., \& Krugman, P.R. (1985). Market Structure and Foreign Trade: Increasing Returns, Imperfect Competition and the International Economy. Cambridge, Mass: MIT Press.

Japan Automobile Manufacturers Association (2019). Retrieved from http://www.jama.or.jp/industry/ebook/bookdata_e/book.pdf on August 28, 2020.

Japan Automobile Manufacturers Association (2020). Retrieved from https://www.jama.org/wp-content/uploads/2019/08/motor-industry-of-japan-2019.pdf on August 28, 2020.

Japan Customs (2020). Retrieved from https://www.customs.go.jp/english/tariff/2019_4/data/e_94.htm on September 4, 2020.

Jošić, H., \& Žmuk, B. (2020). Intra-industry Trade in Croatia: Trends and Determinants. Croatian Economic Survey, 22(1), 5-39. https://doi.org/10.15179/ces.22.1.1

Kierzkowski, H. (1996). Models of International Trade in Differentiated Goods. In D. Greenaway (Ed.) Current Issues in International Trade (pp. 1-19). New York, N.Y.: st. Martin's Press.

Kirchner, E.J., \& Dorussen, H. (2020). New horizons in EU-Japan security cooperation. Asia Europe Journal, July, https://doi.org/10.1007/s10308-020-00586-z

Kojima, K. (1964). The Pattern of International Trade among Advanced Countries. Hitatsubashi Journal of Economics, 5(1), 16-36. https://doi.org/10.15057/8091 
Krugman, P.R. (1979). Increasing Returns, Monopolistic Competition and International Trade. Journal of International Economics, 9, 469-479. https://doi.org/10.1016/0022-1996(79)90017-5

Krugman, P.R. (1981). Intra-Industry Specialisation and Gains from Trade. Journal of Political Economy, 89(5), 959-973. https://doi.org/10.1086/261015

Kuźnar, A., \& Menkes, J. (2019). The EU-Japan relations: Selected aspects. International Entrepreneurship Review, 5(3), 63-78. https://doi.org/10.15678/IER.2019.0503.05

Kuźnar, A., \& Menkes, J. (2019a). EU-Japan agreements: content, context and implications. Review of European and Comparative Law, XXXIX, 7-57. https://doi.org/10.31743/recl.4839

Lancaster, K. (1980). Intra-Industry Trade under Perfect Monopolistic Competition. Journal of International Economics, 10(2), 151-175. https://doi.org/10.1016/0022-1996(80)90052-5

Linder, S.B. (1961). An Essay on Trade and Transformation. New York: John Wiley and Sons.

Ministry of Foreign Affairs (2019). Retrieved from https://www.mofa.go.jp/files/000382109.pdf on September 22, 2020.

Mora, C.D. (2002). The Role of Comparative Advantage in Trade in Industries: A Panel Data Approach for the European Union. Weltwirtschaftliches Archiv, 138(2), 291-315. https://doi.org/10.1007/BF02707746

Posner, M.V. (1961). International Trade and Technical Change. Oxford Economic Papers, 13(3), 323-341. https://doi.org/10.1093/oxfordjournals.oep.a040877

Przeździecka, E., Górska, R., Kuźnar, A., \& Menkes, J. (2019). The Effects of EU-Japan Economic Partnership Agreement for Poland's Economy. Ekonomista, 6, 701-733. Retrieved from https://www.researchgate.net/publication/338458514_The_Effects_of_EU-Japan_Economic_Partnership_Agreement_for_Poland's_Economy on October 14, 2020.

Shaked, A., \& Sutton, J. (1984). National Oligopolies and International Trade. In H. Kierzkowski (Ed.), Monopolistic Competition and International Trade (pp. 34-50). Oxford: Oxford University Press.

Statista (2020). Japan inward FDI from the European Union. Retrieved from https://www.statista.com/statistics/747783/japan-inward-fdi-from-the-european-union/ on October 14, 2020.

Statista (2020a). Japan outward FDI in the European Union. Retrieved from https://www.statista.com/statistics/747770/japan-outward-fdi-in-the-european-union/ on October 14, 2020.

Statista (2020b). Global market share of the leading automakers. Retrieved from https://www.statista.com/statistics/316786/global-market-share-of-the-leading-automakers/ on October 15, 2020.

Sunesen, E., Francois, J., \& Thelle, M. (2010). Assessment of Barriers to Trade and Investment between the EU and Japan. Final Report prepared for the European Union (DG Trade).

Suzuki, H. (2017). The new politics of trade: EU-Japan. Journal of European Integration, 39(7), 875-889. https://doi.org/10.1080/07036337.2017.1371709

Tsukamoto, H. (2006). Japan's Come Back: New Business Development in Asia. Japan External Trade Organization presentation. 2 May

United Nations Comtrade database (2020). Retrieved from https://comtrade.un.org/data on August 14, 2020.

Verdoorn, P.J. (1960). The Intra-Block Trade of Benelux. In E.A.G. Robinson (Ed.), Economic Consequences of the Size of Nations (pp. 291-332). London: Macmillan.

Warner, J. (2019). Renault - Nissan - Mitsubishi alliance - what you need to know. Retrieved from https://www.ig.com/en/news-and-trade-ideas/shares-news/renault-nissan-mitsubishi-alliance--what-youneed-to-know-190404 on October 12, 2020.

Williamson, J., \& Milner, C. (1991). The World Economy: A Textbook in International Economics. New York, London: Harvester/WheatSheaf.

Zarbà, C., Chinnici, G., \& D'Amico, M. (2020). Novel Food: The Impact of Innovation on the Paths of the Traditional Food Chain. Sustainability, 12, 555. https://doi.org/10.3390/su12020555 


\section{Authors}

Contribution share of authors is equal and amounted to $50 \%$ for each of them.

\section{Bogusława Drelich-Skulska}

Full Professor in the Department of International Business at the Wroclaw University of Economics and Business (Poland). MSc in economics and organization of production (Oskar Lange Academy of Economics in Wroclaw), PhD in Economics (Oskar Lange Academy of Economics in Wroclaw), habilitation in Economics (Oskar Lange Academy of Economics in Wroclaw), professorship in Economics (Wroclaw University of Economics). Her research interests include international business, institutional economics, regional economic integration, innovativeness of regions and enterprises.

Correspondence to: prof. dr hab. Bogusława Drelich-Skulska, Wroclaw University of Economics and Business, Department of International Business, ul. Komandorska 118/120, 53-345 Wroclaw, Poland, e-mail: boguslawa.drelich-skulska@ue.wroc.pl

ORCID 가 http://orcid.org/0000-0003-0233-1850

\section{Sebastian Bobowski}

Associate Professor in Department of International Business at the Wroclaw University of Economics and Business (Poland). MSc in International Relations (Oskar Lange Academy of Economics in Wroclaw), PhD in Economics (Wroclaw University of Economics), habilitation in Economics and Finance (Wroclaw University of Economics and Business). His research interests include international economics, regional economic integration, innovativeness of regions and enterprises.

Correspondence to: prof. UEW dr hab. Sebastian Bobowski, Wroclaw University of Economics and Business, Department of International Business, ul. Komandorska 118/120, 53-345 Wroclaw, Poland, e-mail: sebastian.bobowski@ue.wroc.pl

ORCID (i) http://orcid.org/0000-0002-1723-313X

\section{Conflict of Interest}

The authors declare that the research was conducted in the absence of any commercial or financial relationships that could be construed as a potential conflict of interest.

\section{Copyright and License}

This article is published under the terms of the Creative Commons

Attribution - NoDerivs (CC BY-ND 4.0) License

http://creativecommons.org/licenses/by-nd/4.0/ 